\title{
Condition assessment and strengthening of aged structures: Perspectives based on a critical case study
}

\author{
T. Mukhopadhyay ${ }^{\mathrm{a}^{*}}$, S. Naskar ${ }^{\mathrm{b}}$, S. Dey ${ }^{\mathrm{c}}$, A. Chakrabarti $^{\mathrm{d}}$ \\ ${ }^{a}$ Department of Engineering Science, University of Oxford, Oxford, UK \\ ${ }^{\mathrm{b}}$ Whiting School of Engineering, Johns Hopkins University, Baltimore, USA \\ ${ }^{\mathrm{c}}$ Mechanical Engineering Department, National Institute of Technology Silchar, Silchar, India \\ ${ }^{\mathrm{d}}$ Department of Civil Engineering, Indian Institute of Technology Roorkee, Roorkee, India
}

\begin{abstract}
This article presents a concise overview on condition monitoring and retrofitting/ strengthening of structures including a practical case study of strengthening for an existing historical building. Condition assessment of an existing structure is required mainly to check serviceability and safety requirements of the structure after short term events like earthquake or long term degradation of the structure with time. It is carried out to assess the ability of a structure to perform its intended operations under changed loading conditions with time or modification in its structural system as per newly imposed requirements. The condition assessment and strengthening may also be required for integrated extension of an existing structure. After assessing the condition of the structure, either it is retrofitted (or strengthened) or it is demolished according to the severity of the damage. In this article, such a critical condition assessment for an existing historical masonry building is presented and appropriate strengthening schemes are suggested by following two separate measures (concrete jacketing and fiber reinforced polymer strengthening). Subsequently, the relative advantages and disadvantages of the strengthening measures are discussed from a practical engineering perspective. Aim of this article is not to propose any new method for condition assessment and strengthening of structures, rather we take a systematic approach to demonstrate our experience. Critical case studies on condition assessment and strengthening of historical buildings with adequate technical insights are very scarce to find in scientific literature. This article would serve as a valuable reference for the practicing engineers and the concerned scientific community.
\end{abstract}

Keywords: structural health monitoring; condition assessment; FRP strengthening; retrofitting; concrete jacketing

\footnotetext{
* Corresponding author: Tanmoy Mukhopadhyay 


\section{Introduction}

Civil engineering structures are always subjected to considerable amount of risk factor due to their continuous depreciation under time-driven operating and service environments. The condition assessment of an existing structure is required mainly to check serviceability and safety requirements of the structure after short term events like earthquake and fire or long term degradation of the structure with time. Civil engineering structures are constantly subjected to geophysical and human-induced loads during their service life. Such structures are likely to be damaged when loads exceed the capacity of the structures. As construction of a new structure in place of the damaged structures is not often possible due to economic reasons (three-fold economic criteria involved with demolition of the damaged structure, construction of new structure and loss of revenue for the interruption in important functions/ operations of the structures), a decision to repair and strengthen the existing structure can be made at appropriate level. These situations may warrant retrofitting of the structure to continue its intended operations. The decision for strengthening/ retrofitting is taken on the basis of condition assessment. Condition assessment and subsequent strengthening may also be required for integrated extension of an existing structure to investigate its capability to bear additional loads. The purpose is to assess the ability of a structure to perform its intended operations under changed loading conditions with time or modification in its structural system. After assessing the condition of the structure, either it is retrofitted (/strengthened) or it is demolished according to the severity of the damage. Plenty of studies have been reported in the scientific literature on damage modelling (Skrzypek et al. 1998; Nichols and Murphy 2016; Naskar et al. 2017) and damage identification (Mukhopadhyay 2018; Naskar and Bhalla 2015; Mukhopadhyay et al. 2015, 2016a) in structures.

The local strengthening of reinforced concrete members by concrete jacketing is a common mode of retrofitting/ strengthening (Hamid et al. 1994; Bracci et al. 1997; Lakshamanan 2006; Lee et al. 2006). The jacket generally consists of added concrete and 
longitudinal cum transverse reinforcement around the existing structural member. Such type of strengthening improves the axial and shear strength for a column while

the flexural strength of the column and the strength of beam-column joint remain mostly unchanged. Chipping away of concrete cover of original member and roughening its surface is required in this method to improve the bond between the old and new concrete. Fibre reinforced composites have attracted wide attention in the last two decades for an alternative and efficient way of strengthening/retrofitting structural elements (JBDPA 1999; ACI 440, 2000; TCSUK 2000). Application of fibre reinforced polymers (FRP) as reinforcement for structures has gained rapid popularity and appeal due to several advantages like affordability of such materials compared to conventional steel reinforcement or concrete encasements, light weightiness, high strength-to-weight ratio and better quality control (Dey et al. 2017, 2018a, 2018b; Naskar et al. 2018, 2019; Karsh et al. 2018). Moreover, the ease of handling, lack of requirement for heavy lifting and handling equipment and corrosion resistance are some other factors which are advantageous in the repair, retrofitting and rehabilitation of civil engineering structures. Due to continuous research and development on new composite materials (Dey et al. 2015, 2016a, 2016b, 2016c, 2016d, 2016e, 2016f; Mukhopadhyay et al. 2016b), the use of such materials is found to be advantageous in terms of weight-sensitivity and cost-effectiveness. The confinement of reinforced cement concrete (RCC) columns by FRP jackets enhances their strength and ductility. Several researches have been carried out around the world on this issue concerning the enhancement of structural performance by means of FRP (Teng et al. 2000; Antonopoulos and Triantafillou 2003; Bacque et al. 2003; Choi and Xiao 2010; Minicelli and Tegola 2007; Sundarraja and Rajamohan 2009; Smith and Kim 2009; Bank 2006; Kezmane et al. 2016) and it is expected that the design criteria will continue to enhance as the results of these research and development become known in the coming years based on optimal utilization of available resources.

In general, long-term field data are required to accurately predict the life of FRP strengthening systems. The respective design guidelines can be benchmarked to account for 
environmental degradation and long-term durability by suggesting reduction factors for various working environments. The load-carrying capacity of the existing structure is required to be assessed based on the information gathered in the field investigation, the review of design calculations and drawings, and as determined by analytical or other suitable methods. Load tests or other methods can be incorporated into the overall evaluation process if deemed appropriate. However, due to variety of structural conditions during the construction and operational phase, it is not easy to develop general rules for retrofitting. Every strengthening/ retrofitting process for building needs to adopt specific approaches depending upon the structural deficiencies. In the detail retrofitting scheme, it must comply with the latest building codes. The results generated by adopting retrofitting techniques should fulfil the minimum requirements prescribed by the building design codes such as deformation, detailing strength etc. Practical case studies on condition assessment and strengthening of civil engineering structures (particularly buildings) are very scarce to find in literature (Teworte et al. 2015; Bergamo et al. 2014; Livina and Perry 2017; Hadianfard et al. 2017; Alessandri and Turrioni 2017; Cosenzo and Ivervolino 2007; Valluzzi et al. 2005; Verma et al. 2016), even though such studies can be valuable references for practicing engineers and the concerned scientific community. The present article provides a case study on structural condition assessment of an existing building including comprehensive technical discussions. Thereby detail strengthening schemes based on two different approaches are presented for the deficient structural members. Aim of this article is not to propose any novel methodology for structural retrofitting; rather we focus on rendering a practical perspective on this subject. The paper hereafter is organized as: I. brief overview on the technical details of strengthening structural members; II. description of the problem considered for practical case study; III. details of computer modelling of the building; IV. results of structural condition assessment and subsequent strengthening schemes; V. conclusion and outlook. 


\begin{tabular}{c|c|l}
\hline Type & \multicolumn{1}{|c|}{ Application } \\
\hline Flexural & $\begin{array}{l}\text { Schematic diagram } \\
\text { Tension and/or side face } \\
\text { of beam (along long axis } \\
\text { of beam) }\end{array}$ \\
\hline Shear & $\begin{array}{l}\text { Lightweight } \\
\text { (Axial load) }\end{array}$ & $\begin{array}{l}\text { Side face of beam (U- } \\
\text { wrap) (Perpendicular to } \\
\text { long axis of beam) }\end{array}$ \\
\hline
\end{tabular}

Fig. 1 FRP strengthening applications

\section{Strengthening of structural elements}

The strengthening through repair, retrofitting and rehabilitation of civil engineering structures is of paramount significance to reduce the risk and ensure the reliability during service life. Based on assessment of the present condition of an existing building, prudent strengthening schemes can be suggested. Two widely used approaches of structural strengthening are: concrete jacketing and FRP confinement. In both the methods, the space optimization and cost component are needed to be taken into account based on the structure under consideration. Schematic diagrams corresponding to strengthening schemes for 
deficiencies in different types of load carrying capacities for the common structural elements are explained in figure 1 . The figures clearly indicate the position of FRP placement for three different types of load carrying deficiencies.

The strategy followed for concrete jacketing to strengthen a structural element is straight forward. First structural analysis is carried out for a structural member to find out its load carrying capacity. Thereby computer simulation is performed to calculate the loads that different members of a building experience. Comparing the imposed loads on a particular member and its capacity, the deficiency in load carrying capacity is calculated. Based on the deficiency, extra reinforcement $(\varnothing)$ is provided (refer to figure $2(a)$ ) to satisfy the design requirements (Pillai and Menon 2009; Punmia et al. 2006; IS 456 2000; IS 875 1987; IS 1893 2002; IS 13920 1993; ACI 318-05; ACI 440.2R-08). However, for FRP strengthening, a relatively more complex design procedure is needed to be followed (Kezmane 2016, ACI 440.2R-08). As it is found that most of the columns are deficient in load carrying capacity (detailed results are provided later in this paper) in the present problem of strengthening an existing building, a representative strengthening scheme for a column based on FRP confinement is briefly discussed here. The FRP confinement mechanism for a column section is depicted in figure 2(b). For the purpose of demonstration, it is assumed that design forces on a particular column are: $\mathrm{P}_{\mathrm{u}}$ (axial force), $\mathrm{M}_{\mathrm{ux}}$ (moment with respect to x-direction) and $\mathrm{M}_{\mathrm{uy}}$ (moment with respect to y-direction), while the corresponding load carrying capacity of the column are: $\mathrm{P}_{\mathrm{uc}}, \mathrm{M}_{\mathrm{uxc}}$ and $\mathrm{M}_{\mathrm{uyc}}$, respectively. If the load carrying capacity is less than the design forces, the column needs to be strengthened to carry the additional loads. For this purpose FRP wraps can be utilized (ACI 440.2R-08). A bilinear interaction curve is considered for the case of combined axial force and bending to optimize the number of layers for FRP wraps as shown in figure 3. The values of $\phi P_{n}$ and $\phi M_{n}$ are calculated corresponding to the three different points A, B and C as (ACI 440.2R-08)

$$
\phi P_{n(A)}=\phi 0.8\left[0.85 f_{c c}^{\prime}\left(A_{g}-A_{s t}\right)+f_{y} A_{s t}\right]
$$




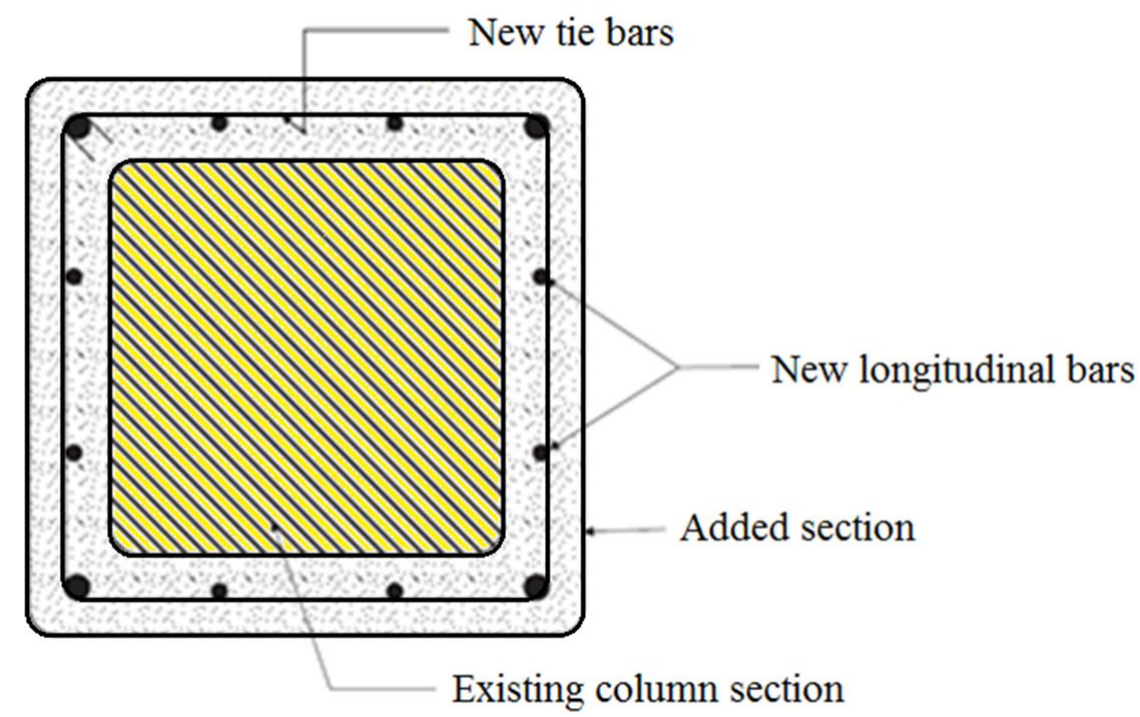

(a)

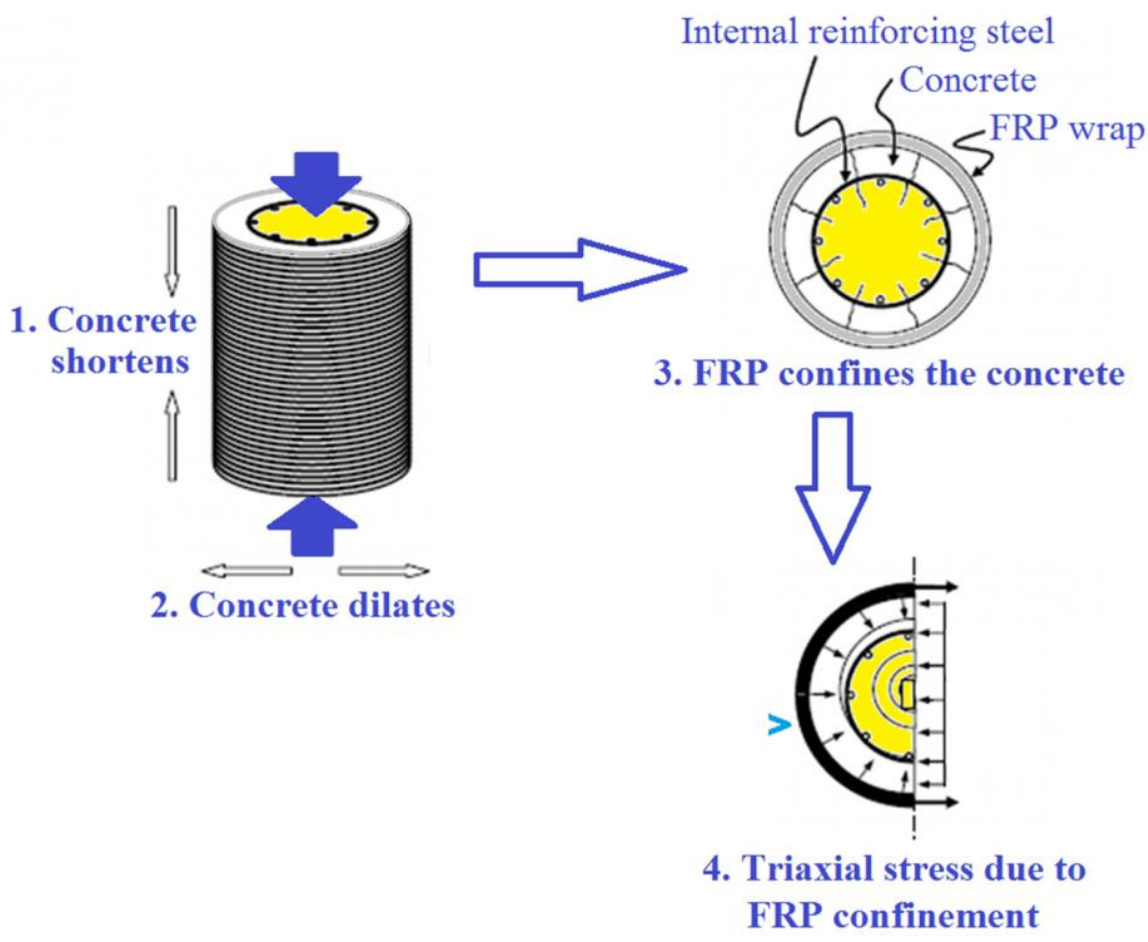

(b)

Fig. 2 Strengthening of column sections using (a) Concrete jacketing for strengthening of column sections (b) Strengthening mechanism of FRP confined concrete columns

$$
\begin{gathered}
\phi P_{n(B, C)}=\phi\left[A\left(y_{t}\right)^{3}+B\left(y_{t}\right)^{2}+C\left(y_{t}\right)+D\right]+\sum A_{s i} f_{s i} \\
\phi M_{n(B, C)}=\phi\left[E\left(y_{t}\right)^{4}+F\left(y_{t}\right)^{3}+G\left(y_{t}\right)^{2}+H\left(y_{t}\right)+I\right]+\sum A_{s i} f_{s i} d_{i}
\end{gathered}
$$

Here the Points $\mathrm{A}, \mathrm{B}$ and $\mathrm{C}$ correspond to three zones of a column section with pure compression caused by a uniform axial compressive strain of unconfined concrete $\left(\varepsilon_{\mathrm{ccu}}\right)$, 


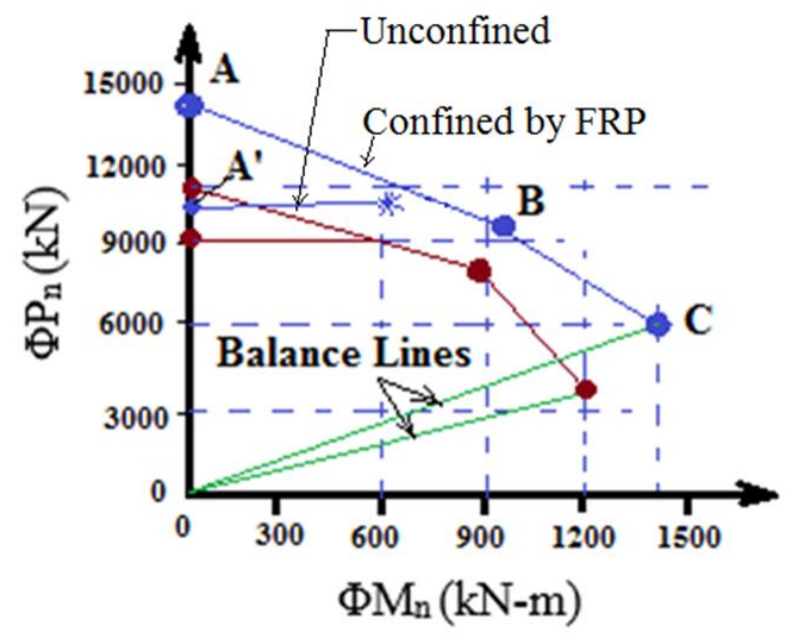

Fig. 3 Typical representation of bilinear interaction curve

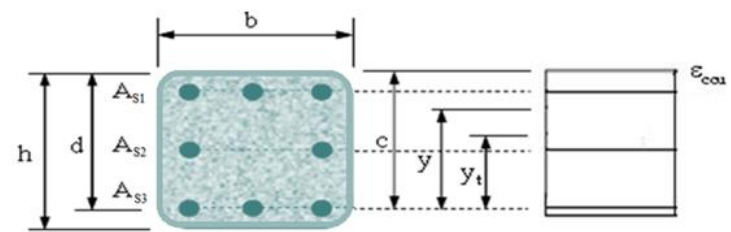

(a) Strain distribution corresponding to Point A

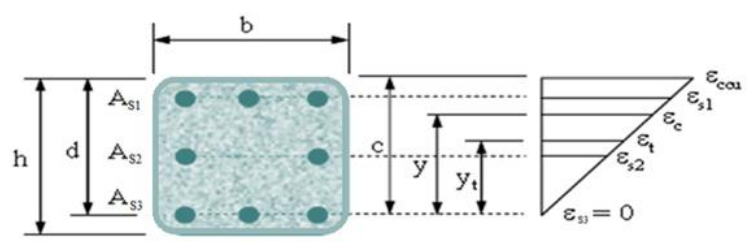

(b) Strain distribution corresponding to Point B

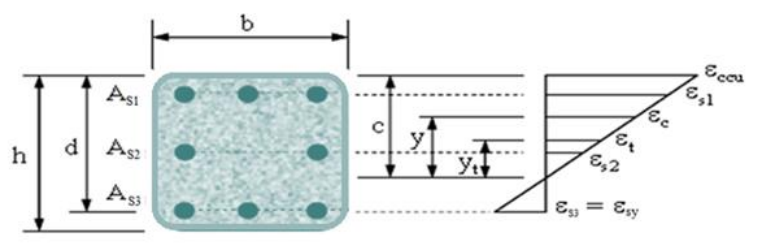

(c) Strain distribution corresponding to Point C

Fig. 4 Strain distributions corresponding to the three points of bilinear interaction curve shown in figure 3

strain distribution corresponding to zero strain at the layer of longitudinal steel reinforcement nearest to the tensile face and compressive strain $\varepsilon_{\mathrm{ccu}}$ on the compression face and strain distribution corresponding to balanced failure, respectively (refer to figure 4) (ACI 440.2R08). A, B, C...H in equation (1) - (3) are the constant coefficients depending on the properties of FRP materials used and can be obtained from expressions provided in ACI 440.2R-08. If the condition of design force and moment interaction point lies in the zone between the bilinear interaction curves corresponding to the unconfined and confined columns, the 
column is designated as safe. A case study of condition assessment and subsequent strengthening for a building is presented in the following sections.

\section{Problem description}

Assessment of the present condition and accordingly strengthening measures were required to be taken for an existing historical library building situated at Uttarakhand, India. The unique G+1 storey building with historical significance was designed and constructed in early 1900s and subsequently one more storey was required to be added due to requirement of expansion of the library building. The building was constructed as RCC framed structure with load bearing brick masonry walls in the periphery. For condition assessment and strengthening of the building, supplied structural drawings of the building have been studied in detail and a separate analysis/design of the building was carried out using ETABS (ETABS 2012) and SAFE (SAFE 2012). To ascertain different parameters used in the aforementioned analysis and design, a site visit was also conducted. This report aims to assess the present condition of the existing library building and to suggest necessary measures of strengthening according to the requirement.

\section{Computer modelling}

The entire building except the foundation has been modelled in ETABS, wherein the beam and columns are modelled using line element as frame (refer to figure 5). Beams and columns provided in the building have different dimensions and orientations. Dimension of the beams and columns are shown in Table 1. The modelling of slabs has been done using shell elements. Shell element is used because the purpose of modelling slab was to transfer loads as well as to provide stiffness to the floor. Shell element helps in analysing the bending behaviour of slabs under various loads. The outer walls of the building are load bearing walls and they have been modelled using shell element for normal elastic analysis. Thickness of slabs, ramps and walls are $75 \mathrm{~mm}, 150 \mathrm{~mm}$ and $250 \mathrm{~mm}$, respectively. Material properties 


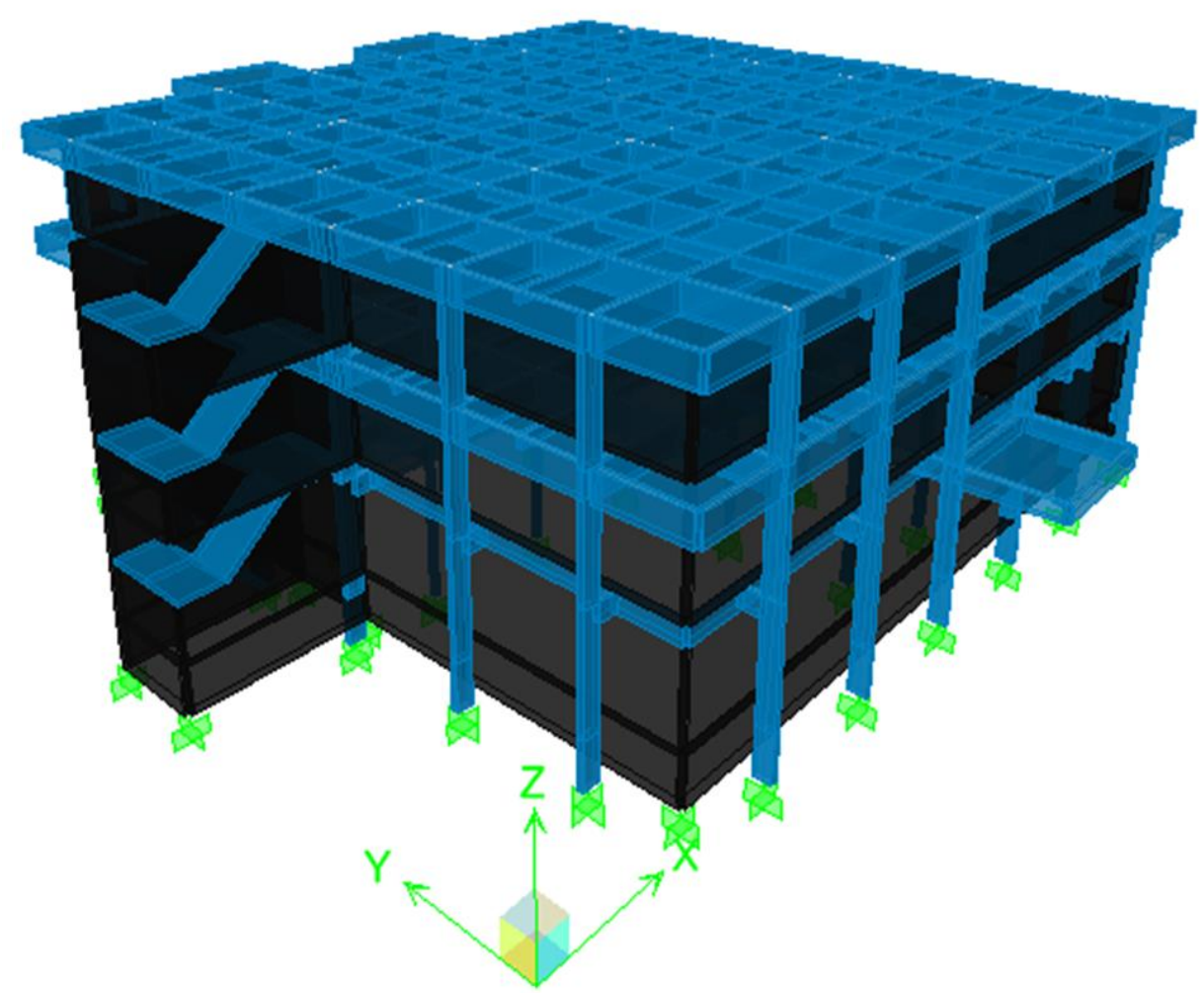

Fig. 5 Typical three dimensional view of the building model

used in the analysis are shown in Table 2 . Reinforcements $(\varnothing)$ have been modelled as per existing drawings. The support conditions at the base have been assigned as no translation and no rotation in any direction, which resembles a fixed support.

Column locations at base level are shown in figure 6. Figure 7 presents the location of beams at the first and second floor level including position of slabs and load bearing walls. To access the requirement of strengthening in the existing structural components of first and second floor level for adding one more storey to the building, the third storey has been modelled in this study as a replica of the second story. Thus beam locations for the roof level are same as figure $7(\mathrm{~b})$. The only difference adopted in computer modelling of the third storey is that no load bearing wall is designed following present construction practices. It should be noted that the existing building was designed and constructed in early 1980s, when framed building structures were not very common. Thus it is expected that the columns in the third storey will need extra reinforcement compared to second storey to balance the effect of 
Table 1 Dimension of beams and column sections (refer to figure 6 and 7)

\begin{tabular}{c|c|c|c}
\hline $\begin{array}{c}\text { Structural } \\
\text { element }\end{array}$ & Type & dimension & Colour code \\
\hline \multirow{2}{*}{ Beam } & Rectangular & $200 \times 750(\mathrm{~mm})$ & Beam Type I \\
& $\begin{array}{l}\text { Rectangular } \\
\text { Rectangular }\end{array}$ & $200 \times 500(\mathrm{~mm})$ & $\begin{array}{c}\text { Beam Type II } \\
\text { Beam Type III }\end{array}$ \\
\hline \multirow{2}{*}{ Column } & Rectangular & $500 \times 200(\mathrm{~mm})$ & Column Type I \\
& $\begin{array}{c}\text { Rectangular } \\
\text { Circular }\end{array}$ & $230 \times 230(\mathrm{~mm})$ & $\begin{array}{c}\text { Column Type II } \\
\text { Column Type III }\end{array}$ \\
\hline
\end{tabular}

Table 2 Material Properties

\begin{tabular}{c|c|c}
\hline Material & Concrete & Masonry \\
\hline Compressive Strength & $20000 \mathrm{KN} / \mathrm{m}^{2}$ & - \\
Mass/Volume & $2.4007 \mathrm{~g} / \mathrm{m}^{3}$ & - \\
Weight/Volume & $24 \mathrm{KN} / \mathrm{m}^{3}$ & $16 \mathrm{KN} / \mathrm{m}^{3}$ \\
Modulus of Elasticity & $22360679.8 \mathrm{KN} / \mathrm{m}^{2}$ & $4200000 \mathrm{KN} / \mathrm{m}^{2}$ \\
Reinforcement Yield Stress & $415000 \mathrm{KN} / \mathrm{m}^{2}$ & - \\
Poisson's Ratio & 0.2 & 0.2 \\
Shear Modulus & $9316949.9 \mathrm{KN} / \mathrm{m}^{2}$ & $1750000 \mathrm{KN} / \mathrm{m}^{2}$ \\
\hline
\end{tabular}

removing load bearing walls. The requirement of extra reinforcement can be taken care of effectively while designing the new storey.

\section{Results and discussion}

The dead load and live load considered as per codal provisions (IS 875 1987) in this study are shown in Table 3. For considering earthquake loading as per IS 18932002 (Part 1), different parameters used are as follows: zone factor: 0.24 (seismic zone IV), response 
Table 3 Static loads considered in the design

\begin{tabular}{l|c|c}
\hline & Roof & $0.22 \mathrm{KN} / \mathrm{m}^{2}$ \\
$\begin{array}{c}\text { Super Imposed } \\
\text { Dead Load }\end{array}$ & $2^{\text {nd }}$ Floor & $0.20 \mathrm{KN} / \mathrm{m}^{2}$ \\
& 1st Floor & $0.20 \mathrm{KN} / \mathrm{m}^{2}$ \\
\hline \multirow{2}{*}{ Live Load } & Roof & $1.5 \mathrm{KN} / \mathrm{m}^{2}$ \\
& $2^{\text {nd }}$ Floor & $3 \mathrm{KN} / \mathrm{m}^{2}$ \\
1st Floor & $6 \mathrm{KN} / \mathrm{m}^{2}$ \\
& Ramps and landing of staircase & $4 \mathrm{KN} / \mathrm{m}^{2}$ \\
\hline
\end{tabular}

Table 4 Different loading combinations considered in the analysis with appropriate factor of safety (DL: Dead load; SD: Super imposed dead load; LL: Live load; EQX and EQY: Earthquake loadings in two perpendicular directions)

\begin{tabular}{c|c}
\hline Sl. No. & Design combinations \\
\hline 1. & $1.5(\mathrm{DL}+\mathrm{SD})$ \\
\hline 2. & $1.2(\mathrm{DD}+\mathrm{SD}+\mathrm{LL}+\mathrm{EQX})$ \\
\hline 3. & $1.2(\mathrm{DD}+\mathrm{SD}+\mathrm{LL}-\mathrm{EQX})$ \\
\hline 4. & $1.2(\mathrm{DD}+\mathrm{SD}+\mathrm{LL}+\mathrm{EQY})$ \\
\hline 5. & $1.2(\mathrm{DD}+\mathrm{SD}+\mathrm{LL}-\mathrm{EQY})$ \\
\hline 6. & $1.5(\mathrm{DL}+\mathrm{SD}+\mathrm{EQX})$ \\
\hline 7. & $1.5(\mathrm{DL}+\mathrm{SD}-\mathrm{EQX})$ \\
\hline 8. & $1.5(\mathrm{DL}+\mathrm{SD}+\mathrm{EQY})$ \\
\hline 9. & $1.5(\mathrm{DL}+\mathrm{SD}-\mathrm{EQY})$ \\
\hline 10. & $0.9(\mathrm{DL}+\mathrm{SD})+1.5 \mathrm{EQX}$ \\
\hline 11. & $0.9(\mathrm{DL}+\mathrm{SD})-1.5 \mathrm{EQX}$ \\
\hline 12. & $0.9(\mathrm{DL}+\mathrm{SD})+1.5 \mathrm{EQY}$ \\
\hline 13. & $0.9(\mathrm{DL}+\mathrm{SD})-1.5 \mathrm{EQY}$ \\
\hline 14. &
\end{tabular}




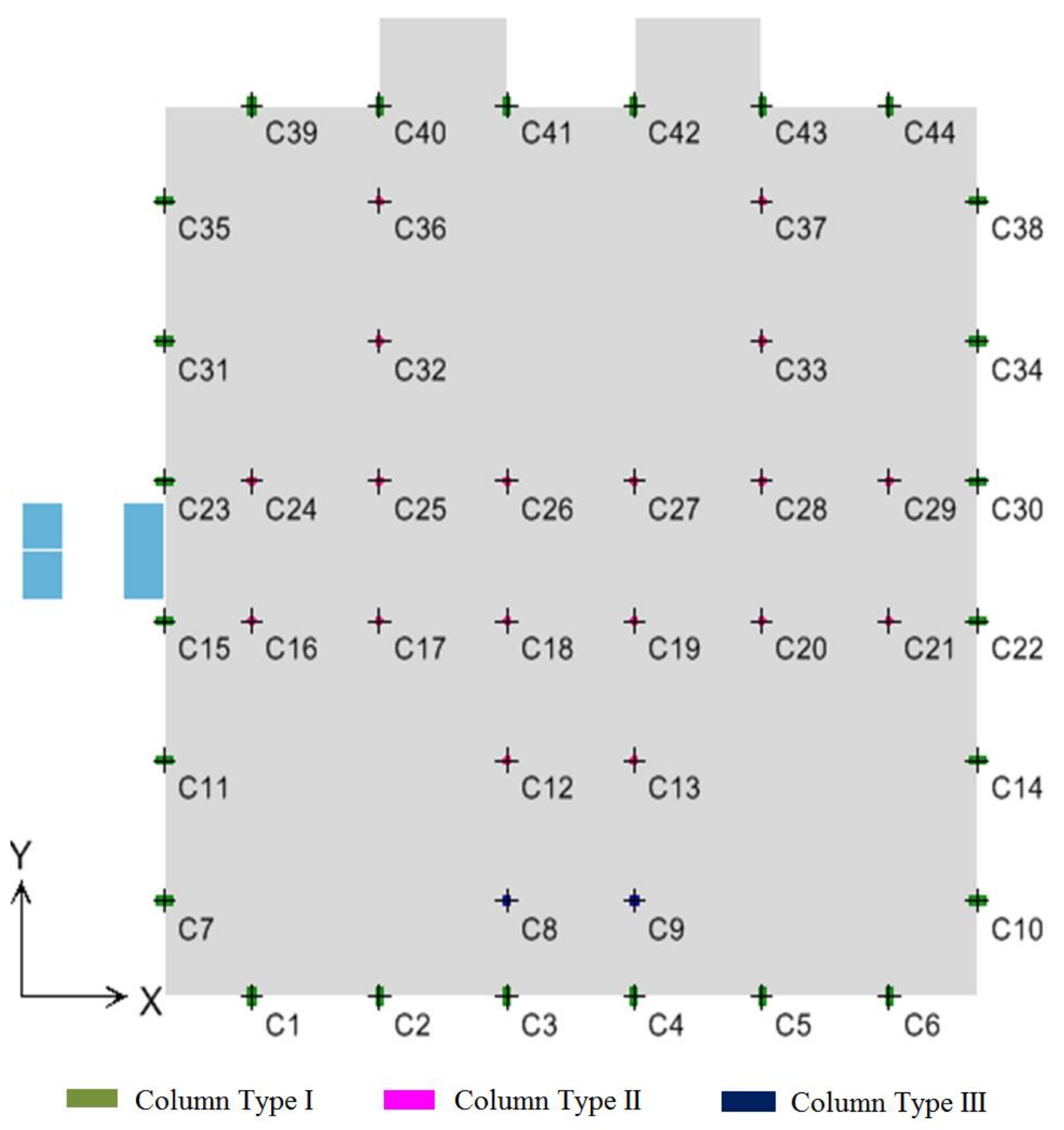

Fig. 6 Plan View of building including column positions (refer Table 1 for colour codes)

reduction factor: $3(\mathrm{OMRF})$, importance factor: 1.5 (important service and community building), damping factor: 0.05 (RCC structures), soil type: medium. As the problem under consideration is not of high rise building, effect of wind loading has not been accounted in the analysis. Different loading combinations that have been analysed to access performance of the structural components are shown in Table 4 including the factor of safety values as per codal provisions. A particular structural component is considered as 'failed' if it fails in any one of the loading case. For analysing the foundations, allowable bearing pressure considered at a depth of $2 \mathrm{~m}$ below the ground surface is $8 \mathrm{t} / \mathrm{m}^{2}$, as per soil testing report. 


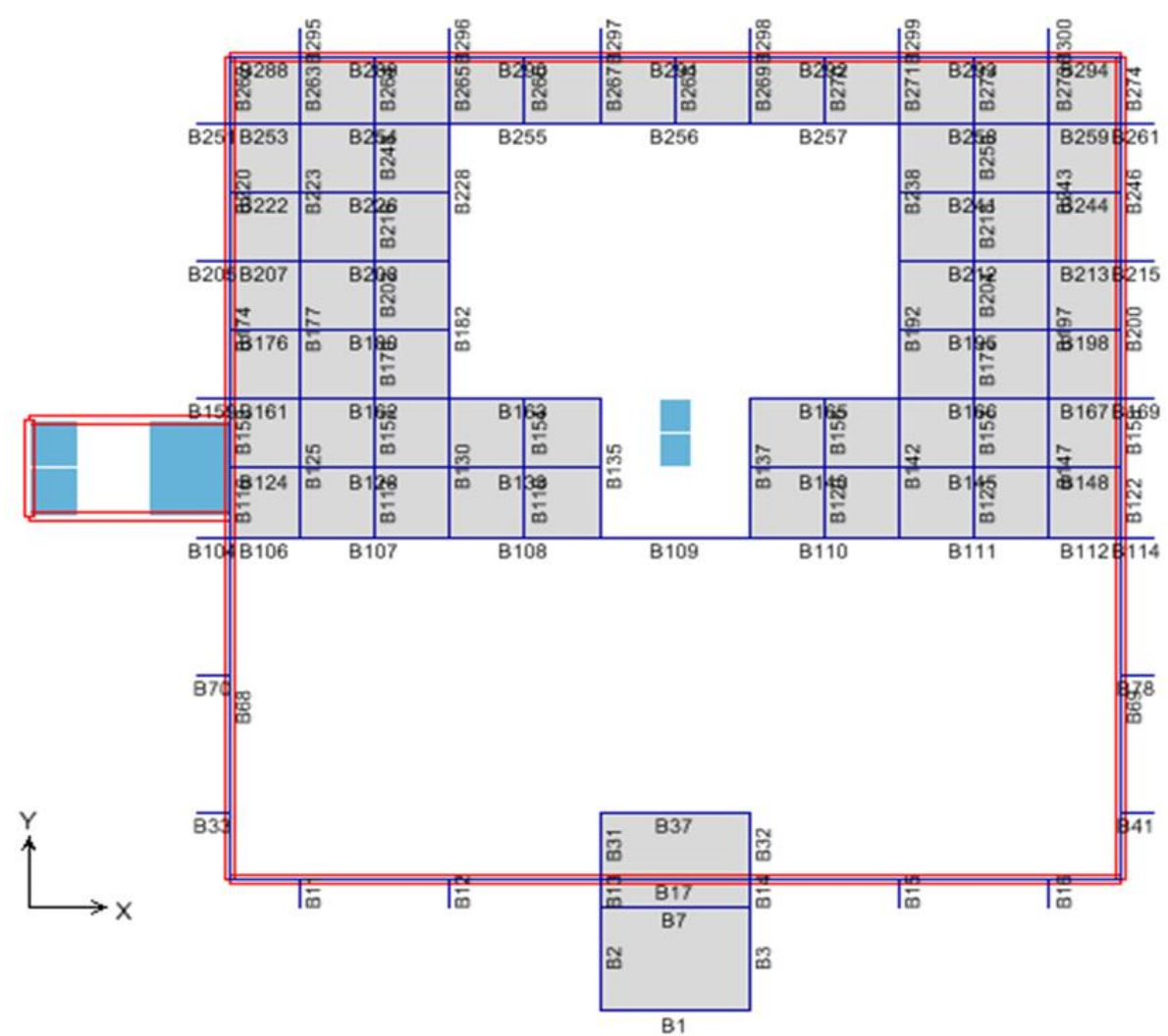

Beam Type I

Beam Type II

Beam Type III

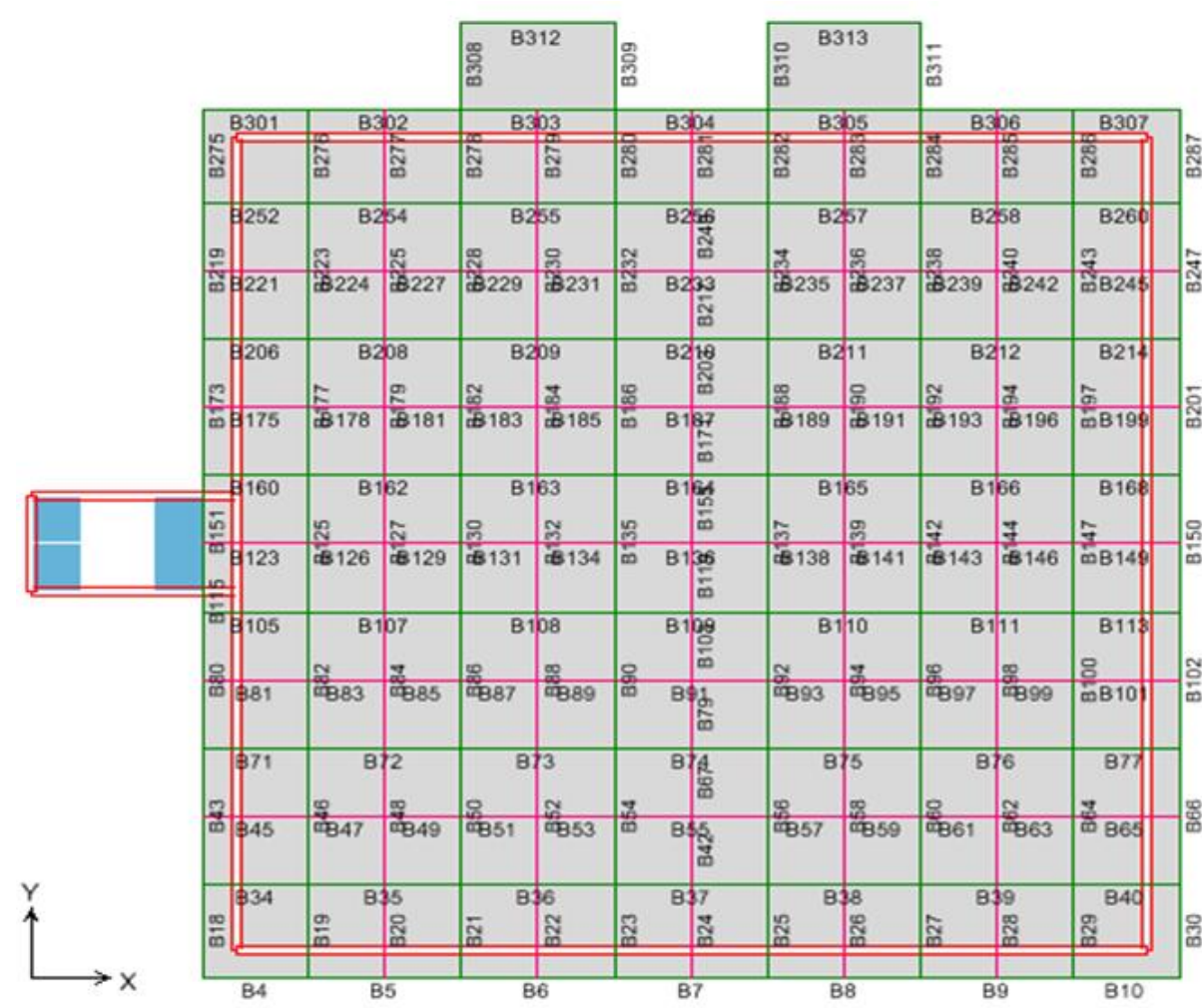

Beam Type I

Beam Type II

Beam Type III

Fig. 7 Location of beams with different dimensions (refer Table 1) in (a) first floor level and (b) second floor level. The rectangular areas in sky blue colour show position of the landing slabs of staircase and double lines in red colour at the periphery indicate location of load bearing brick masonry walls. Filling in grey colour indicates location of slab. 


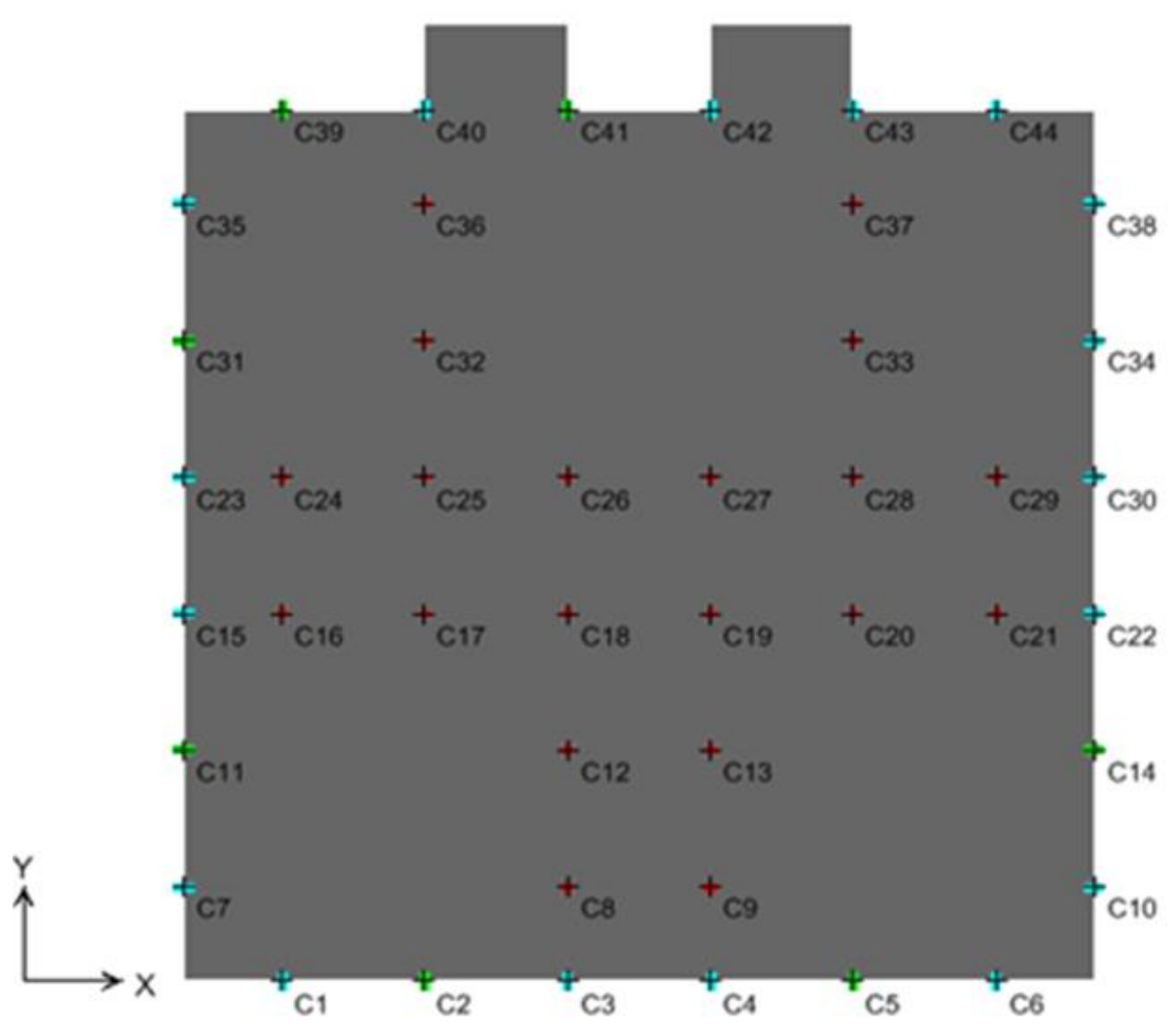

(a)

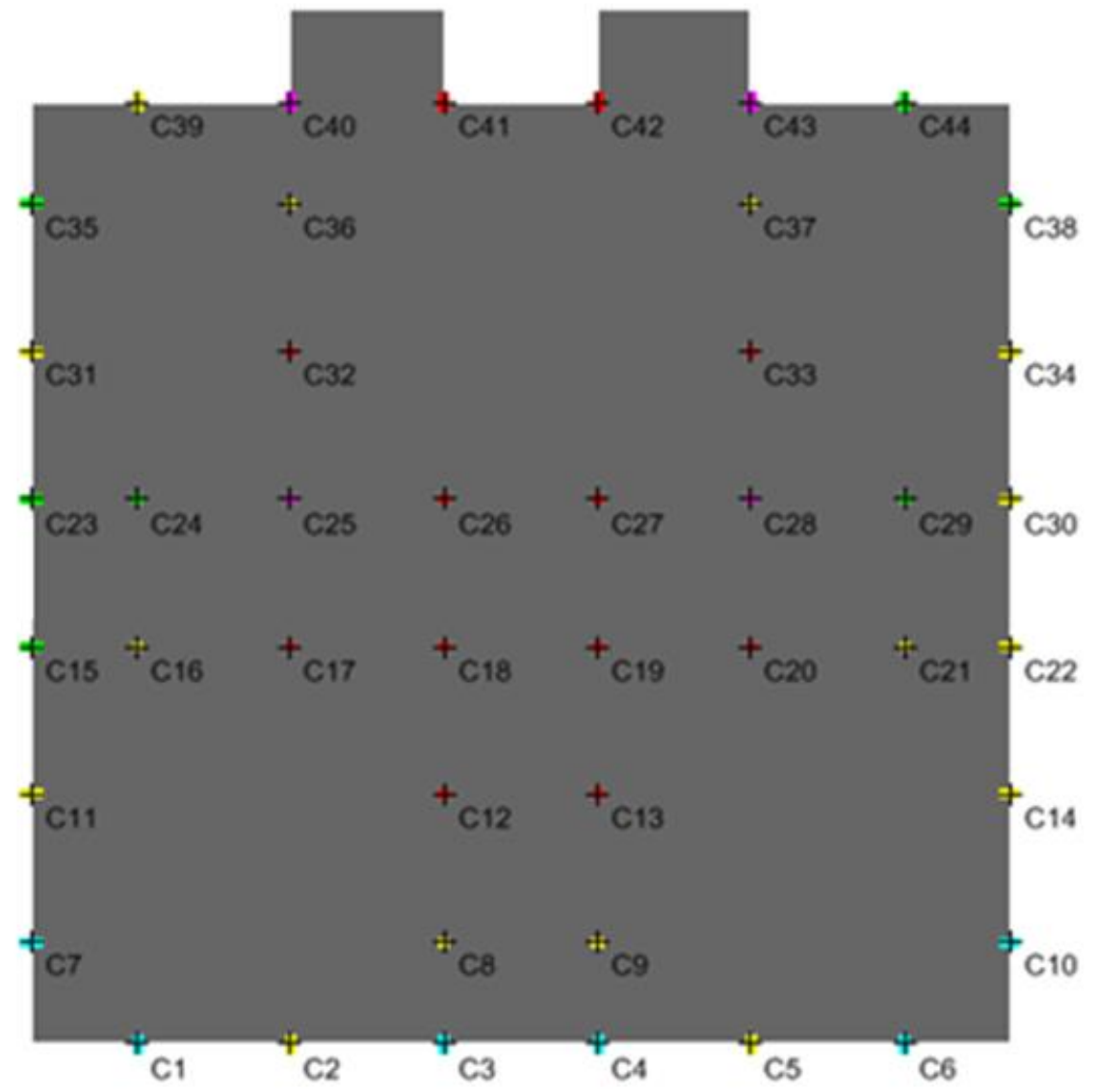

(b)

Fig. 8 Location of failed columns at (a) third storey (b) second storey. Failed columns are indicated in red colour (these columns are strengthened). Other colours indicate different levels of safety as per design requirements (green being the safest, followed by blue, yellow and pink). The grey colour indicates the position of slabs in a particular floor. 


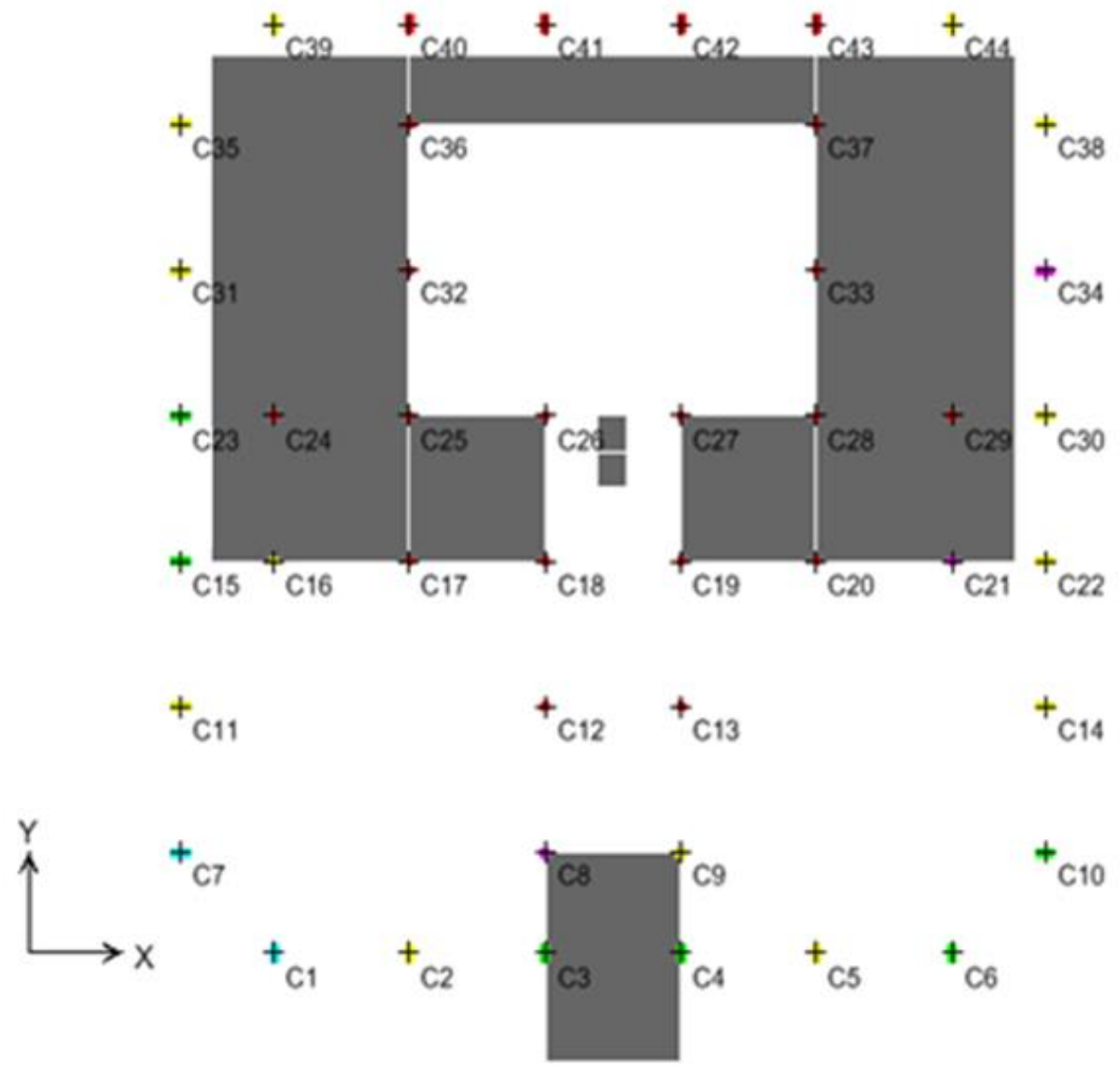

(a)

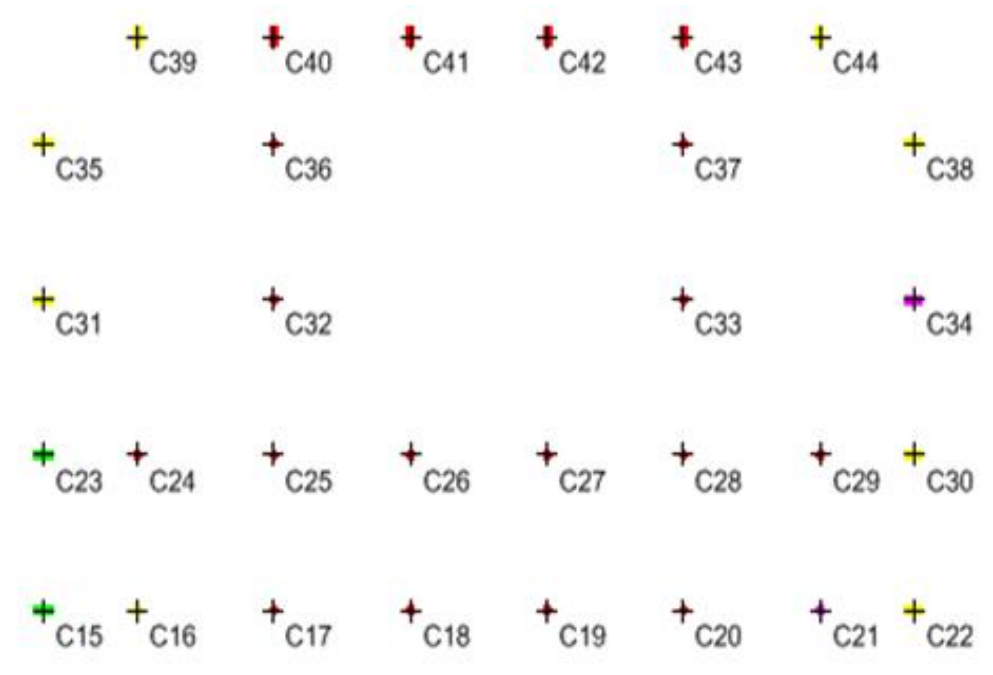

$+{ }_{\text {C11 }}$

$+_{\mathrm{C} 12}+{ }_{\mathrm{C} 13}$

$+_{C 14}$
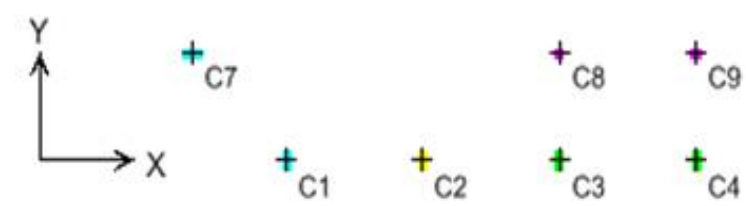

${ }^{+}{ }_{\mathrm{C} 10}$

$+_{\mathrm{C} 3}+{ }_{\mathrm{C} 4}+{ }_{\mathrm{C} 5}+{ }_{\mathrm{C} 6}$

(b)

Fig. 9 Location of failed columns at (a) first storey (b) base level (Ground). Failed columns are indicated in red colour (these columns are strengthened). Other colours indicate different levels of safety as per design requirements (green being the safest, followed by blue, yellow and pink). The grey colour indicates the position of slabs in a particular floor. 


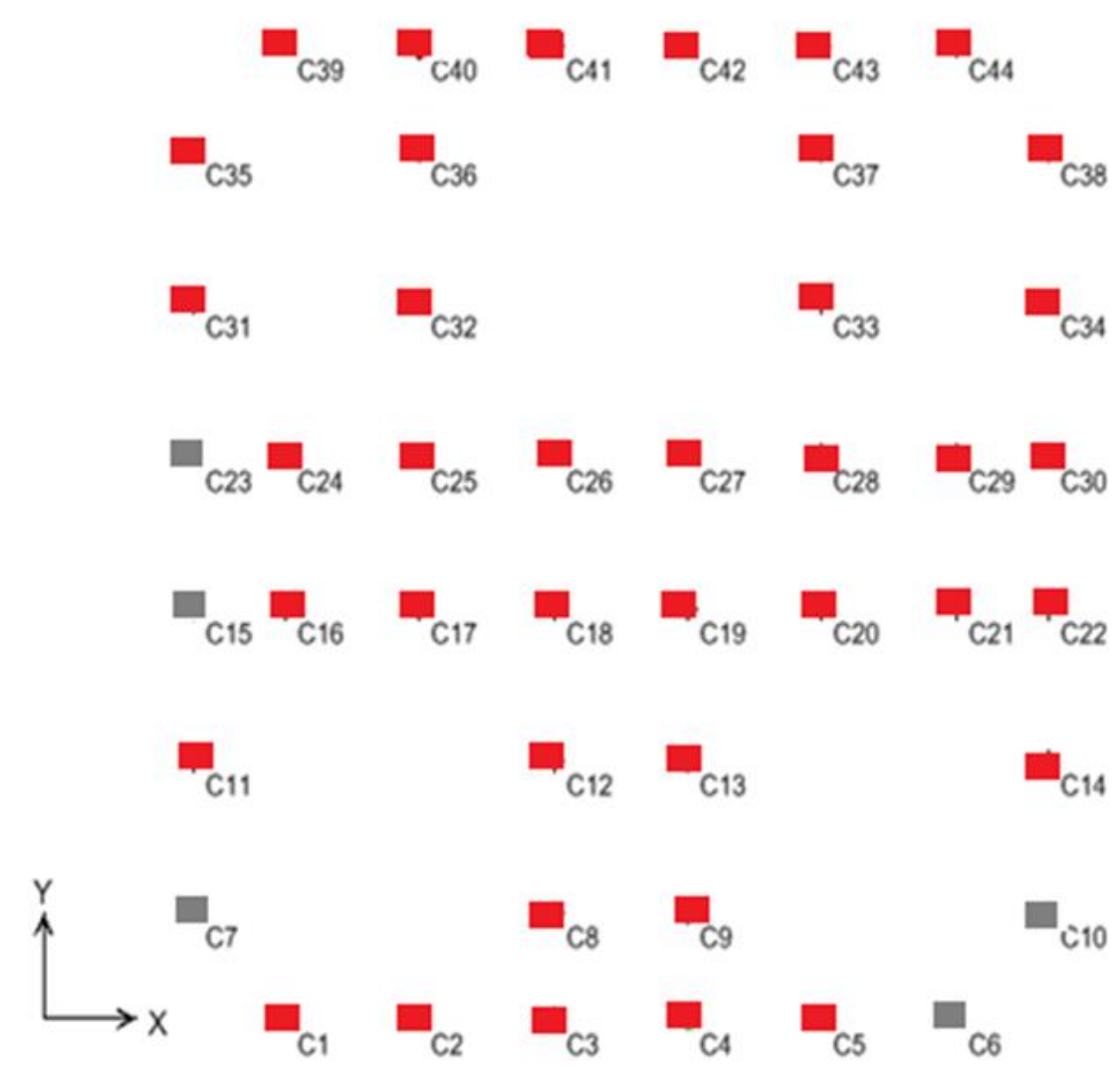

Fig. 10 Location of failed foundations (indicated in red colour)

\section{Condition assessment}

In the present analysis, it is observed that beams and slabs remain safe after the addition of extra storey. This is quite expected as the extra static loads are supposed to be transferred through the columns of first and second floor to the foundations. Several columns at different levels (refer to figure 8 and 9) and foundations (refer to figure 10) are found to be unsafe after the proposed expansion. The foundations failed due to gross bearing pressure of soil.

\section{Strengthening schemes}

For the strengthening of the columns, two different schemes (concrete jacketing and FRP strengthening) have been explored in this project. The adopted strengthening measures using concrete jacketing (increase in dimension and reinforcement, as required; refer to figure 2(a)) for the failed columns at different sections are presented in Table 5 (detailed results are shown in APPENDIX: Table A1-A4). It should be noted here that the requirement for 
Table 5 Proposed strengthening schemes for the failed columns of first storey (detailed results are shown in APPENDIX: Table A1- A4)

\begin{tabular}{|c|c|c|c|c|c|c|c|}
\hline $\begin{array}{l}\text { Column } \\
\text { number }\end{array}$ & $\begin{array}{l}\text { Existing } \\
\text { Size } \\
\left(\mathrm{mm}^{2}\right)\end{array}$ & $\begin{array}{l}\text { Proposed } \\
\text { Size } \\
\left(\mathrm{mm}^{2}\right)\end{array}$ & $\begin{array}{c}\text { Existing } \\
\text { Reinforcement } \\
\left(\mathrm{mm}^{2}\right)\end{array}$ & $\begin{array}{c}\text { Rebar } \\
\text { Percentage }\end{array}$ & $\begin{array}{c}\text { Reinforcement } \\
\text { Required } \\
\left(\mathrm{mm}^{2}\right)\end{array}$ & $\begin{array}{c}\text { Additional } \\
\text { Reinforcement } \\
\text { Required }\left(\mathrm{mm}^{2}\right)\end{array}$ & $\begin{array}{l}\text { Extra } \\
\text { Bars }\end{array}$ \\
\hline $\mathrm{C} 12$ & $230 \varnothing$ & $330 \varnothing$ & 1205.76 & 0.95 & 812.1 & 0 & \\
\hline $\mathrm{C} 17$ & $230 \varnothing$ & $330 \varnothing$ & 1205.76 & 1.94 & 1658.4 & 452.6 & $4-12 \varnothing$ \\
\hline $\mathrm{C} 20$ & $230 \varnothing$ & $330 \varnothing$ & 1205.76 & 1.92 & 1641.3 & 435.5 & 4- $12 \varnothing$ \\
\hline $\mathrm{C} 24$ & $230 \varnothing$ & $330 \varnothing$ & 1205.76 & 0.8 & 683.8 & 0 & \\
\hline $\mathrm{C} 25$ & $230 \varnothing$ & $330 \varnothing$ & 1205.76 & 1.18 & 1008.7 & 0 & \\
\hline $\mathrm{C} 26$ & $230 \varnothing$ & $330 \varnothing$ & 1205.76 & 2.01 & 1718.2 & 512.5 & 4- $16 \varnothing$ \\
\hline $\mathrm{C} 43$ & $500 \times 200$ & $600 \times 300$ & 1440 & 0.8 & 1440 & 0 & \\
\hline
\end{tabular}

Table 6 Manufacturer's reported FRP system properties

\begin{tabular}{c|c}
\hline Thickness of ply $\left(t_{f}\right)$ & $0.33 \mathrm{~mm}$ \\
\hline Ultimate tensile strength $\left(f_{f u}\right)$ & $3792 \mathrm{MPa}$ \\
\hline Rupture strain $\left(\varepsilon_{f u}\right)$ & 0.017 \\
\hline Modulus of elasticity $\left(E_{f}\right)$ & $227.523 \mathrm{MPa}$ \\
\hline
\end{tabular}

Table 7 Capacity of the column before ( $n=0$ plies $)$ and after $(n=6$ plies $)$ FRP strengthening

\begin{tabular}{c|c|c|c|c}
\hline \multirow{2}{*}{ Points } & \multicolumn{2}{|c|}{$\mathrm{n}=0$ (plies) } & \multicolumn{2}{c}{$\mathrm{n}=6$ (plies) } \\
\cline { 2 - 5 } & $\Phi \mathrm{P}_{\mathrm{n}}(\mathrm{kN})$ & $\Phi \mathrm{M}_{\mathrm{n}}(\mathrm{kN}-\mathrm{m})$ & $\Phi \mathrm{P}_{\mathrm{n}}(\mathrm{kN})$ & $\Phi \mathrm{M}_{\mathrm{n}}(\mathrm{kN}-\mathrm{m})$ \\
$\mathrm{A}$ & 9133.54 & 0 & 10331 & 0 \\
$\mathrm{~B}$ & 6998 & 196 & 7856 & 359 \\
$\mathrm{C}$ & 3127 & 378 & 5639 & 489 \\
\hline
\end{tabular}

increased dimension and reinforcement for third storey (new addition) can be taken care of during new construction.

Representative results for FRP strengthening is presented for column C41 as per the guidelines of ACI 440.2R-08. From the structural analysis results, the design forces 
Table 8 Proposed strengthening schemes for foundations (detailed results are shown in APPENDIX: Table A5)

\begin{tabular}{c|c|c|c|c|c}
\hline Column & Existing Size & Remarks & Proposed & \multicolumn{2}{|c}{ Depth } \\
\cline { 5 - 6 } & & & size & existing & Proposed \\
\hline C1 & $2500 \times 980$ & Valid Design & & & \\
C2 & $2500 \times 980$ & Fails on GBP & $2500 \times 1065$ & 450 & 450 \\
C3 & $2500 \times 980$ & Fails on GBP & $2500 \times 1255$ & 450 & 450 \\
C4 & $2500 \times 980$ & Fails on GBP & $2500 \times 1270$ & 450 & 450 \\
C5 & $2500 \times 980$ & Fails on GBP & $2500 \times 1170$ & 450 & 450 \\
& & & - & & \\
& & & - & & \\
C44 & $2500 \times 980$ & Fails on GBP & $2500 \times 1135$ & 450 & 450 \\
\hline
\end{tabular}

obtained for the column are: $\mathrm{P}_{\mathrm{u}}=7321.55 \mathrm{kN} ; \mathrm{M}_{\mathrm{ux}}=170.25 \mathrm{kN}-\mathrm{m}$ and $\mathrm{M}_{\mathrm{uy}}=2.295 \mathrm{kN}-\mathrm{m}$ (negligible). However, capacity of the column is: $\mathrm{P}_{\mathrm{uc}}=6000 \mathrm{kN}$ and $\mathrm{M}_{\mathrm{uxc}}=156 \mathrm{kN}-\mathrm{m}$. So it is required to increase the load demand by $22 \%$ at constant eccentricity. The properties of FRP used in this study are given in Table 6. A wrapping system composed of 6 plies has been used for the strengthening by constructing the bilinear curve (refer to figure 3). Typical results for 6 plies are shown in Table 7, wherein it is clear that if six plies are used for the purpose of strengthening, the column becomes safe under the applied loading conditions. However, the design can be optimized further by trying lesser number of plies. Due to addition of the extra storey, several footings are found to be unsafe as indicated in figure 10. As the foundations fail due to gross bearing pressure (GBP), it has been recommended to increase dimension of the foundations as per requirements (refer to Table 8 and Table A5).

\section{Discussion}

In this paper we have discussed a critical study concerning the strengthening of an aged building. It can be noted that the intension of this article is not to propose any new methodology; rather we have adopted some of the well-established techniques here. The building was actually designed for G+1 storey and it was mentioned in the structural drawings that no further storey should be constructed over the existing building. However, 
due to requirement of vertical expansion owing to the purpose of capacity enhancement, one extra storey is proposed to be added leading to a requirement of strengthening the existing structure. The library building being a monumental structure with historical significance, demolition and subsequent reconstruction of a new building is not an option in this case. In general, such masonry buildings share a large percentage of the current building stock in most parts of the world. The use of unreinforced masonry (URM) for load bearing walls in these buildings is a common practice. The URM walls are normally prone to failure under seismic in-plane and out-of-plane deformations. The in-plane behaviour of URM walls is crucial, as it provides the primary load path for transfer of seismic loads. However, URM has also very low tensile strength and hence, the URM walls are highly vulnerable to out-of-plane flexure. The contemporary design guidelines, which were followed during construction of the buildings, were not very sophisticated to account for the effect of earthquake loading. Thus to ensure the modern safety and serviceability requirements, these buildings are often needed to be strengthened as per the latest codal provisions. Due to sustained policies of several governments worldwide, old structures are encouraged to be strengthened/ retrofitted according to modern design guidelines for economic benefits and to preserve monumental structures of historical significance (Power 2010; Fernandez 2017). Computer modelling of the present $\mathrm{G}+2$ storey library building reveals that several columns and footings fail to satisfy the design requirement as per latest codal provisions. In most of the cases, the size of the columns are increased with minor or no change in the area of longitudinal reinforcements for concrete jacketing (Pillai and Menon 2009, IS 15988 2013). Most of the footings fail due to soil bearing pressure. Mostly the depth and size of the column footings are suggested to be increased without significantly changing the area of the reinforcements so as to make the strengthening work feasible (refer to figure 11) (Thermou and Elnashai 2006; Website 2019). No major action of strengthening is required to be taken for beams and slabs. Though here the columns are strengthened by following two different schemes: concrete jacketing and FRP strengthening, future investigations can be carried out to investigate other potential 


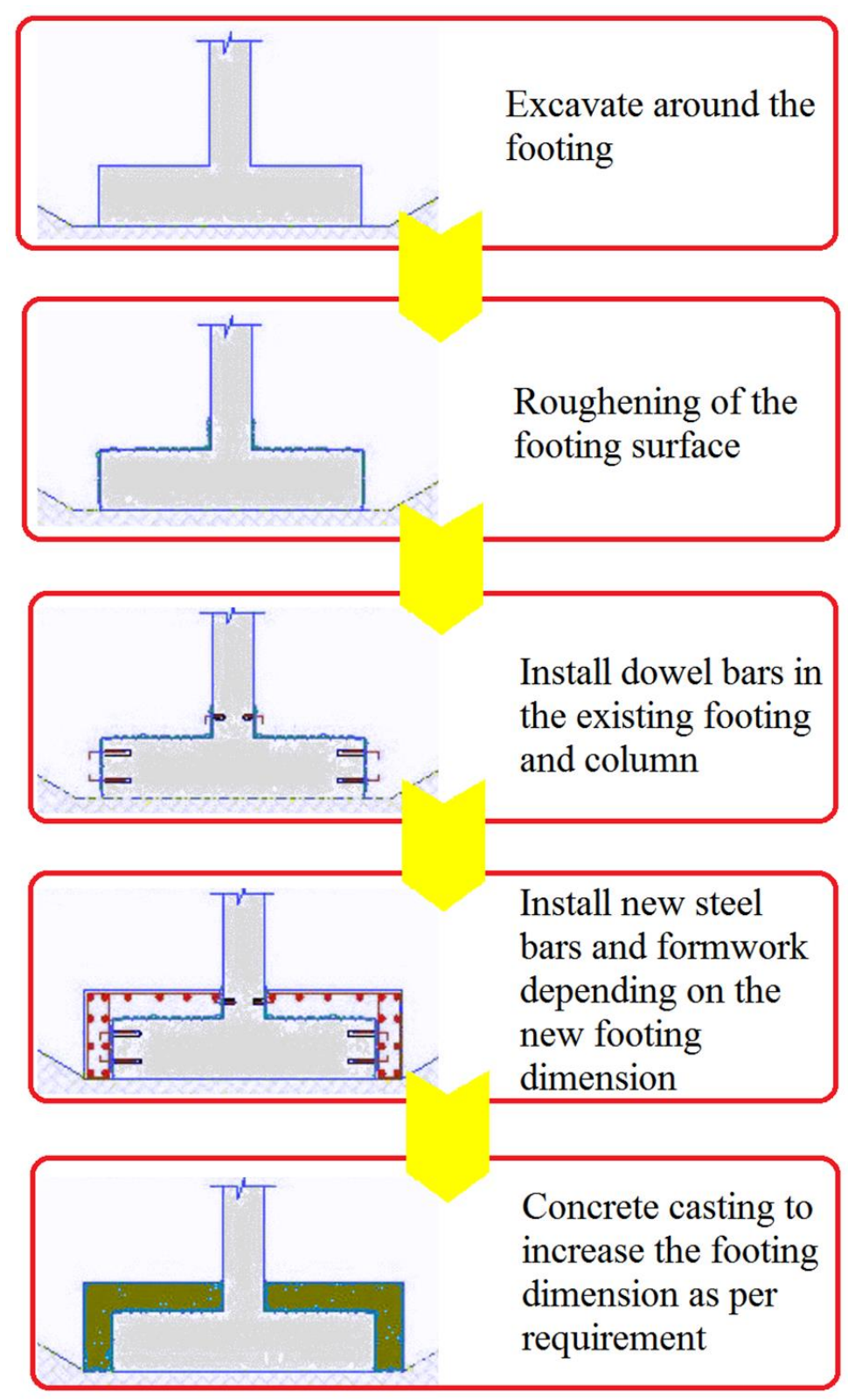

Fig. 11 Strengthening scheme for column footings

methods of strengthening such as steel-jacketing (Campione et al. 2017; Ferrotto et al. 2018).

In view of the above discussion, it is observed that most of the columns and footings are required to be strengthened for the safety of the library building. From a construction point of view, though the columns can be easily strengthened either by using FRP or by concrete jacketing, but strengthening the footings by increasing their size is difficult due to involvement of excavation. FRP strengthening may be a superior choice than concrete jacketing for strengthening of columns form the viewpoint of space optimization. A direct comparative economic assessment on the basis of the cost of materials can be carried out 
based on the detailed strengthening scheme presented in this article considering the concrete jacketing and FRP strengthening. The issue of cost effectiveness of the two prospective methods should be accounted before choosing the most suitable option for strengthening of a particular structural element. The execution of such strengthening works should be decided at appropriate level based on economical and constructional feasibility.

\section{Conclusion}

A brief overview of condition assessment and strengthening for existing structures has been presented in this article. To illustrate the topic further a practical problem has been considered concerning strengthening the structural elements of a historical library building, which is examined for the purpose of prospective vertical expansion. Even though the beams and slabs do not need any major strengthening measure due to addition of an extra storey, several columns and footings are found to fail as per the existing structural configuration. For strengthening the columns, two different schemes (concrete jacketing and FRP strengthening) have been explored and detail results are presented. The footings are found to fail due to gross bearing pressure of soil and therefore, to strengthen the footings, their dimensions have been increased in most of the cases. Monumental structures with historical significance are often required to be strengthened or retrofitted, instead of a complete demolition and subsequent reconstruction. Moreover, due to sustained policies of several governments worldwide, old structures are encouraged to be strengthened/ retrofitted according to modern codal provisions ensuring various safety and serviceability criteria, after appropriate condition assessment instead of constructing a new structure in place of the old one. As practical case studies on condition assessment and strengthening of civil engineering structures with adequate technical insights are very scarce to find in published literature, this article on the critical aspects of structural health monitoring of historical old buildings is expected to serve as a valuable reference for practicing engineers and the concerned scientific community. 


\section{Acknowledgement}

The authors would like to acknowledge the financial support received from MHRD, India during the period of this work.

\section{References}

1. ACI (American Concrete Institute) 318-05, Building Code Requirements for Structural Concrete and Commentary

2. ACI (American Concrete Institute) 440, 2000: Guide for the Design and Strengthening of Externally Bonded FRP Systems for Strengthening Concrete Structures-draft report dated 12 July 2000 by ACI Committee 440, American Concrete Institute.

3. ACI (American Concrete Institute) 440.2R-08, Guide for the Design and Construction of Externally Bonded FRP Systems for Strengthening Concrete Structures

4. Alessandri C., Turrioni J. (2017) "The Church of the Nativity in Bethlehem: Analysis of a Local Structural Consolidation", International Journal of Civil Engineering, DOI: 10.1007/s40999-017-0148-0

5. Antonopoulos C P, Triantafillou T C (2003) "Experimental Investigation of FRPStrengthened R.C. Beam-Column Joints", Journal of Composites for Construction, 7(1) 39-49

6. Bacque J, Patnaik A K, Rizkalla S H (2003) "Analytical Models for Concrete Confined with FRP Tubes”, Journal of Composites for Construction, 7(1), pp. 31-38

7. Bank L C (2006) Composites for construction: Structural design with FRP materials, John Wiley \& Sons, Inc., Hoboken, New Jersey

8. Bergamo O, Russo G, Donadello S (2014) "Retrofitting of the Historic Castagnara Bridge in Padua, Italy, with Fibre Reinforced Plastic Elements", Structural Engineering International, 24 (4) 532-543

9. Bracci J M, Kunnath S K, Reinhorn A M (1997). "Seismic performance and retrofit evaluation of reinforced concrete structures", Journal of Structural Engineering, ASCE, 123 (1) 3-10

10. Campione G., Cavaleri L., Di Trapani F., Ferrotto M.F. (2017) "Frictional effects on structural behavior of no-end-connected steel-jacketed RC columns: Experimental results and new approaches to model numerical and analytical response", J. Struct. Eng. ASCE, 143 04017070. DOI: 10.1061/(ASCE)ST.1943-541X.0001796

11. Choi K K, Xiao Y (2010) "Analytical Studies of Concrete-Filled Circular Steel Tubes under Axial Compression”, Journal of Structural Engineering, 136(5), 565-578

12. Cosenzo E and Ivervolino I (2007) "Case Study Seismic Retrofitting of a Medieval Bell Tower with FRP”, Journal of Composites for Construction, 11(3) 319-327

13. Dey S., Mukhopadhyay T., Khodaparast H. H., Adhikari S. (2015) "Stochastic natural frequency of composite conical shells", Acta Mechanica, 226 (8) 2537-2553

14. Dey S., Mukhopadhyay T., Adhikari S. (2017) "Metamodel based high-fidelity stochastic analysis of composite laminates: A concise review with critical comparative assessment", Composite Structures, 171 227-250 
15. Dey S., Mukhopadhyay T., Adhikari S. (2018a) Uncertainty quantification in laminated composites: A meta-model based approach, CRC Press, ISBN 9781498784450

16. Dey S., Mukhopadhyay T., Khodaparast H. H., Adhikari S. (2016c) "Fuzzy uncertainty propagation in composites using Gram-Schmidt polynomial chaos expansion", Applied Mathematical Modelling, 40 (7-8) 4412-4428

17. Dey S., Mukhopadhyay T., Khodaparast H. H., Adhikari S. (2016f) “A response surface modelling approach for resonance driven reliability based optimization of composite shells", Periodica Polytechnica - Civil Engineering, 60 (1) 103-111

18. Dey S., Mukhopadhyay T., Sahu S. K., Adhikari S. (2016a) "Effect of cutout on stochastic natural frequency of composite curved panels", Composites Part B: Engineering, 105, 188-202

19. Dey S., Mukhopadhyay T., Sahu S. K., Adhikari S. (2018b) "Stochastic dynamic stability analysis of composite curved panels subjected to non-uniform partial edge loading", European Journal of Mechanics / A Solids, 67 108-122

20. Dey S., Mukhopadhyay T., Spickenheuer A., Adhikari S., Heinrich G. (2016e) "Bottom up surrogate based approach for stochastic frequency response analysis of laminated composite plates", Composite Structures, 140 712-727

21. Dey S., Mukhopadhyay T., Spickenheuer A., Gohs U., Adhikari S. (2016b) "Uncertainty quantification in natural frequency of composite plates - An Artificial neural network based approach", Advanced Composites Letters, 25(2) 43-48

22. Dey S., Naskar S., Mukhopadhyay T., Gohs U., Sriramula S., Adhikari S., Heinrich G. (2016d) "Uncertain natural frequency analysis of composite plates including effect of noise - A polynomial neural network approach”, Composite Structures, 143 130142

23. ETABS 2012, Computers \& Structures Inc., California, USA

24. Fernandez S. (2017) "Demolition is not always the answer: breathing new life into a 1960s building", Proceedings of the Institution of Civil Engineers - Civil Engineering, doi: 10.1680/jcien.17.00017

25. Ferrotto M.F., Cavaleri L., Papia M. (2018) "Compressive response of substandard steel-jacketed RC columns strengthened under sustained service loads: From the local to the global behaviour", Construction and Building Materials 179 500-511

26. Hadianfard M. A., Rabiee R., Sarshad A. (2017) "Assessment of Vulnerability and Dynamic Characteristics of a Historical Building Using Microtremor Measurements", International Journal of Civil Engineering, 15 (2) 175-183

27. Hamid A A, Mohmond A D S, El Magal S A (1994) "Strengthening and Repair of Unreinforced Masonry Structures: State-of-the-art", Proceedings of the 10th International Brick and Block Masonry Conference, Vol. 2, Elsevier Applied Science, London, 485-497

28. IS (Indian Standard) 13920:1993, Ductile detailing of reinforced concrete structures subjected to seismic forces - Code of practice

29. IS (Indian Standard) 875 :1987, Code of Practice for Design Loads for Buildings and Structures

30. IS (Indian Standard) 15988 : 2013, Seismic Evaluation and Strengthening of Existing Reinforced Concrete Buildings - Guidelines 
31. IS (Indian Standard) 1893 : 2002, Criteria for Earthquake Resistant Design of Structures

32. IS (Indian Standard) 456: 2000, Plain and Reinforced Concrete - Code of Practice

33. JBDPA (Japan Building Disaster Prevention Association). (1999) Seismic Retrofitting Design and Construction Guidelines for Existing Reinforced Concrete (RC) Buildings with FRP Materials, In Japanese.

34. Karsh P. K., Mukhopadhyay T., Dey S. (2018) "Spatial vulnerability analysis for the first ply failure strength of composite laminates including effect of delamination", Composite Structures, 184 554-567

35. Kezmane, A., Boukais, S., Hamizi, M. (2016) "Numerical simulation of squat reinforced concrete wall strengthened by FRP composite material", Frontiers of Structural and Civil Engineering, 10(4), 445-455

36. Lakshamanan N (2006). "Seismic Evaluation and Retrofitting of buildings and structures", ISET Journal of Earthquake Technology, 43 (1-2) 31-48.

37. Lee, M G, Kan Y C and Chen K C (2006). "A Preliminary Study of RPC for Repair and Retrofitting Materials", Journal of the Chinese Institute of Engineers, 29 (6) 1099-1103

38. Livina V., Perry M. (2017) "Structural health monitoring of infrastructure with sensors: from detection to prevention", Proceedings of the Institution of Civil Engineers - Civil Engineering, 170 (2) 52-52

39. Minicelli F and Tegola L A (2007) "Strengthening Masonry Columns: Steel Strands Versus FRP", Proceedings of the Institution of Civil Engineers - Construction Materials, 160 47-55

40. Mukhopadhyay T.(2018) “A multivariate adaptive regression splines based damage identification methodology for web core composite bridges including the effect of noise", Journal of Sandwich Structures \& Materials, 20(7) 885-903

41. Mukhopadhyay T., Chowdhury R., Chakrabarti A. (2016a) "Structural damage identification: A random sampling-high dimensional model representation approach", Advances in Structural Engineering, 19(6) 908-927

42. Mukhopadhyay T., Dey T. K.,Chowdhury R., Chakrabarti A.(2015) "Structural damage identification using response surface based multi-objective optimization: A comparative study", Arabian Journal for Science and Engineering, 40 (4) 1027-1044

43. Mukhopadhyay T., Naskar S., Dey S., Adhikari S. (2016b) "On quantifying the effect of noise in surrogate based stochastic free vibration analysis of laminated composite shallow shells", Composite Structures, 140 798-805

44. Naskar S., Mukhopadhyay T., Sriramula S. (2018) "Probabilistic micromechanical spatial variability quantification in laminated composites", Composites Part B: Engineering, 151 291-325

45. Naskar S., Mukhopadhyay T., Sriramula S. (2019) "Spatially varying fuzzy multiscale uncertainty propagation in unidirectional fibre reinforced composites", Composite Structures, 209 940-967

46. Naskar S., Mukhopadhyay T., Sriramula S., Adhikari S. (2017) "Stochastic natural frequency analysis of damaged thin-walled laminated composite beams with uncertainty in micromechanical properties", Composite Structures, 160 312-334 
47. Naskar, S. \& Bhalla, S. (2015). "Metal-wire-based twin one-dimensional orthogonal array configuration of PZT patches for damage assessment of two-dimensional structures", Journal of Intelligent Material Systems and Structures, 27(11), 1440-1460

48. Nichols J. M., Murphy K. D. (2016) Modeling and Estimation of Structural Damage, Wiley, ISBN:9781118776995

49. Pillai, S. U. \& Menon, D. (2009) Reinforced Concrete Design, Tata McGraw Hill, New Delhi

50. Power A. (2010) "Housing and sustainability: demolition or refurbishment?", Proceedings of the Institution of Civil Engineers - Urban Design and Planning, 163(4) 205-216

51. Punmia B.C., Jain A. K., Jain A. K. (2006) Reinforced Concrete Structures, Laxmi Publication (P) Limited, New Delhi

52. SAFE 2012, Computers \& Structures Inc., California, USA

53. Skrzypek J. J., Ganczarski A., Altenbach H. (1998) Modeling of Material Damage and Failure of Structures: Theory and Applications, Springer, ISBN 978-3540637257

54. Smith S T, Kim S J (2009) "Strengthening of one-way spanning RC slabs with cutouts using FRP composites", Journal of construction and building materials, 23(4) 1578-1590

55. Sundarraja M C, Rajamohan S (2009) "Strengthening of RC beams in shear using GFRP inclined strips-An experimental study", Journal of construction and building materials, 23(2) 856-864

56. TCSUK (The Concrete Society UK) 2000: Technical Report No. 55 - Design guidance for strengthening concrete structures using fibre composite materials - ISBN 0946691843.

57. Teng, J., Lam, L., Chan, W., and Wang, J. (2000) "Retrofitting of Deficient RC Cantilever Slabs Using GFRP Strips", Journal of Composites for Construction, 2(75) 75-84

58. Teworte F, Herbrand M, Hegger J (2015) "Structural Assessment of Concrete Bridges in Germany-Shear Resistance under Static and Fatigue Loading", Structural Engineering International, 25 (3) 266-274

59. Valluzzi M R, Binda L, Modena C (2005) "Mechanical behaviour of historic masonry structures strengthened by bed joints structural repointing", Construction and Building Materials, 19(1) 63-73

60. Verma, S. K., Bhadauria, S. S., Akhtar, S. (2016) "In-situ condition monitoring of reinforced concrete structures", Frontiers of Structural and Civil Engineering, 10(4), 420-437

61. Webpage: theconstructor.org (Accessed on 2 February 2019)

62. Thermou, G. E., and A. S. Elnashai (2006) "Seismic retrofit schemes for RC structures and local-global consequences." Progress in Structural Engineering and Materials 8 (1) 1-15 


\section{APPENDIX}

Table A1 Proposed strengthening schemes for the failed columns of third storey

\begin{tabular}{|c|c|c|c|c|c|c|c|}
\hline $\begin{array}{l}\text { Column } \\
\text { number }\end{array}$ & $\begin{array}{l}\text { Existing } \\
\text { Size } \\
\left(\mathrm{mm}^{2}\right)\end{array}$ & $\begin{array}{l}\text { Proposed } \\
\text { Size } \\
\left(\mathrm{mm}^{2}\right)\end{array}$ & $\begin{array}{c}\text { Existing } \\
\text { Reinforcement } \\
\left(\mathrm{mm}^{2}\right)\end{array}$ & $\begin{array}{c}\text { Rebar } \\
\text { Percentage }\end{array}$ & $\begin{array}{l}\text { Reinforcement } \\
\text { Required } \\
\left(\mathrm{mm}^{2}\right)\end{array}$ & $\begin{array}{c}\text { Additional } \\
\text { Reinforcement } \\
\text { Required }\left(\mathrm{mm}^{2}\right)\end{array}$ & $\begin{array}{c}\text { Extra } \\
\text { Bars }\end{array}$ \\
\hline $\mathrm{C} 8$ & $230 \times 230$ & $330 \times 330$ & 803.84 & 0.8 & 871.2 & 68 & $4-12 \varnothing$ \\
\hline C9 & $230 \times 230$ & $330 \times 330$ & 803.84 & 0.8 & 871.2 & 68 & $4-12 \varnothing$ \\
\hline C12 & $230 \varnothing$ & $330 \varnothing$ & 1205.76 & 0.8 & 683.8 & 0 & \\
\hline C13 & $230 \varnothing$ & $330 \varnothing$ & 1205.76 & 0.8 & 683.8 & 0 & \\
\hline C16 & $230 \varnothing$ & $330 \varnothing$ & 1205.76 & 0.8 & 683.8 & 0 & \\
\hline C17 & $230 \varnothing$ & $330 \varnothing$ & 1205.76 & 0.8 & 683.8 & 0 & \\
\hline C18 & $230 \varnothing$ & $330 \varnothing$ & 1205.76 & 0.8 & 683.8 & 0 & \\
\hline C19 & $230 \varnothing$ & $330 \varnothing$ & 1205.76 & 0.8 & 683.8 & 0 & \\
\hline $\mathrm{C} 20$ & $230 \varnothing$ & $330 \varnothing$ & 1205.76 & 0.8 & 683.8 & 0 & \\
\hline $\mathrm{C} 21$ & $230 \varnothing$ & $330 \varnothing$ & 1205.76 & 0.8 & 683.8 & 0 & \\
\hline $\mathrm{C} 24$ & $230 \varnothing$ & $330 \varnothing$ & 1205.76 & 0.8 & 683.8 & 0 & \\
\hline $\mathrm{C} 25$ & $230 \varnothing$ & $330 \varnothing$ & 1205.76 & 0.8 & 683.8 & 0 & \\
\hline $\mathrm{C} 26$ & $230 \varnothing$ & $330 \varnothing$ & 1205.76 & 0.9 & 769.3 & 0 & \\
\hline $\mathrm{C} 27$ & $230 \varnothing$ & $330 \varnothing$ & 1205.76 & 0.9 & 769.3 & 0 & \\
\hline C28 & $230 \varnothing$ & $330 \varnothing$ & 1205.76 & 0.8 & 683.8 & 0 & \\
\hline C29 & $230 \varnothing$ & $330 \varnothing$ & 1205.76 & 0.8 & 683.8 & 0 & \\
\hline C32 & $230 \varnothing$ & $330 \varnothing$ & 1205.76 & 0.8 & 683.8 & 0 & \\
\hline C33 & $230 \varnothing$ & $330 \varnothing$ & 1205.76 & 0.8 & 683. & 0 & \\
\hline C36 & $230 \varnothing$ & $330 \varnothing$ & 1205.76 & 0.8 & 683.8 & 0 & \\
\hline C37 & $230 \varnothing$ & $330 \varnothing$ & 1205.76 & 0.8 & 683.8 & 0 & \\
\hline
\end{tabular}

Table A2 Proposed strengthening schemes for the failed columns of second storey

\begin{tabular}{|c|c|c|c|c|c|c|c|}
\hline $\begin{array}{l}\text { Column } \\
\text { number }\end{array}$ & $\begin{array}{c}\text { Existing } \\
\text { Size } \\
\left(\mathrm{mm}^{2}\right)\end{array}$ & $\begin{array}{c}\text { Proposed } \\
\text { Size } \\
\left(\mathrm{mm}^{2}\right) \\
\end{array}$ & $\begin{array}{c}\text { Existing } \\
\text { Reinforcement } \\
\left(\mathrm{mm}^{2}\right)\end{array}$ & $\begin{array}{c}\text { Rebar } \\
\text { Percentage }\end{array}$ & $\begin{array}{l}\text { Reinforcement } \\
\text { Required } \\
\left(\mathrm{mm}^{2}\right)\end{array}$ & $\begin{array}{c}\text { Additional } \\
\text { Reinforcement } \\
\text { Required }\left(\mathrm{mm}^{2}\right) \\
\end{array}$ & $\begin{array}{c}\text { Extra } \\
\text { Bars }\end{array}$ \\
\hline $\mathrm{C} 12$ & $230 \varnothing$ & $330 \emptyset$ & 1205.76 & 0.87 & 743.7 & 0 & \\
\hline $\mathrm{C} 13$ & $230 \varnothing$ & $330 \varnothing$ & 1205.76 & 0.88 & 752.2 & 0 & \\
\hline C17 & $230 \varnothing$ & $330 \varnothing$ & 1205.76 & 1.18 & 1008.7 & 0 & \\
\hline $\mathrm{C} 18$ & $230 \varnothing$ & $330 \varnothing$ & 1205.76 & 0.8 & 683.8 & 0 & \\
\hline C19 & $230 \varnothing$ & $330 \varnothing$ & 1205.76 & 0.8 & 683.8 & 0 & \\
\hline $\mathrm{C} 20$ & $230 \varnothing$ & $330 \varnothing$ & 1205.76 & 1.17 & 1000.1 & 0 & \\
\hline $\mathrm{C} 26$ & $230 \varnothing$ & $330 \varnothing$ & 1205.76 & 1.37 & 1171.1 & 0 & \\
\hline $\mathrm{C} 27$ & $230 \varnothing$ & $330 \varnothing$ & 1205.76 & 1.37 & 1171.1 & 0 & \\
\hline $\mathrm{C} 32$ & $230 \varnothing$ & $330 \varnothing$ & 1205.76 & 2.19 & 1872.1 & 666.3 & $4-16 \varnothing$ \\
\hline $\mathrm{C} 33$ & $230 \varnothing$ & $330 \emptyset$ & 1205.76 & 2.07 & 1769.5 & 563 & 4- $16 \varnothing$ \\
\hline C41 & $500 \times 200$ & $600 \times 300$ & 1440 & 0.8 & 1440 & 0 & \\
\hline $\mathrm{C} 42$ & $500 \times 200$ & $600 \times 300$ & 1440 & 0.8 & 1440 & 0 & \\
\hline
\end{tabular}


Table A3 Proposed strengthening schemes for the failed columns of first storey

\begin{tabular}{|c|c|c|c|c|c|c|c|}
\hline $\begin{array}{l}\text { Column } \\
\text { number }\end{array}$ & $\begin{array}{l}\text { Existing } \\
\text { Size } \\
\left(\mathrm{mm}^{2}\right) \\
\end{array}$ & $\begin{array}{c}\text { Proposed } \\
\text { Size } \\
\left(\mathrm{mm}^{2}\right) \\
\end{array}$ & $\begin{array}{c}\text { Existing } \\
\text { Reinforcement } \\
\left(\mathrm{mm}^{2}\right)\end{array}$ & $\begin{array}{c}\text { Rebar } \\
\text { Percentage }\end{array}$ & $\begin{array}{c}\text { Reinforcement } \\
\text { Required } \\
\left(\mathrm{mm}^{2}\right)\end{array}$ & $\begin{array}{c}\text { Additional } \\
\text { Reinforcement } \\
\text { Required }\left(\mathrm{mm}^{2}\right) \\
\end{array}$ & $\begin{array}{c}\text { Extra } \\
\text { Bars }\end{array}$ \\
\hline $\mathrm{C} 12$ & $230 \varnothing$ & $330 \varnothing$ & 1205.76 & 0.95 & 812.1 & 0 & \\
\hline $\mathrm{C} 13$ & $230 \varnothing$ & $330 \varnothing$ & 1205.76 & 0.96 & 820.6 & 0 & \\
\hline C17 & $230 \varnothing$ & $330 \varnothing$ & 1205.76 & 1.94 & 1658.4 & 452.6 & $4-12 \varnothing$ \\
\hline $\mathrm{C} 18$ & $230 \varnothing$ & $330 \varnothing$ & 1205.76 & 0.8 & 683.8 & 0 & \\
\hline C19 & $230 \varnothing$ & $330 \varnothing$ & 1205.76 & 0.8 & 683.8 & 0 & \\
\hline $\mathrm{C} 20$ & $230 \varnothing$ & $330 \varnothing$ & 1205.76 & 1.92 & 1641.3 & 435.5 & $4-12 \varnothing$ \\
\hline $\mathrm{C} 24$ & $230 \varnothing$ & $330 \varnothing$ & 1205.76 & 0.8 & 683.8 & 0 & \\
\hline $\mathrm{C} 25$ & $230 \varnothing$ & $330 \varnothing$ & 1205.76 & 1.18 & 1008.7 & 0 & \\
\hline $\mathrm{C} 26$ & $230 \varnothing$ & $330 \varnothing$ & 1205.76 & 2.01 & 1718.2 & 512.5 & 4- $16 \varnothing$ \\
\hline $\mathrm{C} 27$ & $230 \varnothing$ & $330 \varnothing$ & 1205.76 & 2.04 & 1743.9 & 538.1 & $4-16 \varnothing$ \\
\hline $\mathrm{C} 28$ & $230 \varnothing$ & $330 \varnothing$ & 1205.76 & 1.16 & 991.6 & 0 & \\
\hline $\mathrm{C} 29$ & $230 \varnothing$ & $330 \varnothing$ & 1205.76 & 0.8 & 683.8 & 0 & \\
\hline $\mathrm{C} 32$ & $230 \varnothing$ & $330 \varnothing$ & 1205.76 & 2.79 & 2385 & 1179 & $4-20 \varnothing$ \\
\hline $\mathrm{C} 33$ & $230 \varnothing$ & $330 \varnothing$ & 1205.76 & 2.67 & 2282.4 & 1076 & $4-20 \varnothing$ \\
\hline $\mathrm{C} 36$ & $230 \varnothing$ & $330 \varnothing$ & 1205.76 & 1.04 & 889 & 0 & \\
\hline $\mathrm{C} 37$ & $230 \varnothing$ & $330 \varnothing$ & 1205.76 & 0.8 & 683.8 & 0 & \\
\hline $\mathrm{C} 40$ & $500 \times 200$ & $600 \times 300$ & 1440 & 0.8 & 1440 & 0 & \\
\hline C41 & $500 \times 200$ & $600 \times 300$ & 1440 & 0.8 & 1440 & 0 & \\
\hline $\mathrm{C} 42$ & $500 \times 200$ & $600 \times 300$ & 1440 & 0.8 & 1440 & 0 & \\
\hline $\mathrm{C} 43$ & $500 \times 200$ & $600 \times 300$ & 1440 & 0.8 & 1440 & 0 & \\
\hline
\end{tabular}

Table A4 Proposed strengthening schemes for the failed columns at base level (ground)

\begin{tabular}{|l|c|c|c|c|c|c|c|}
\hline $\begin{array}{c}\text { Column } \\
\text { number }\end{array}$ & $\begin{array}{c}\text { Existing } \\
\text { Size } \\
\left(\mathrm{mm}^{2}\right)\end{array}$ & $\begin{array}{c}\text { Proposed } \\
\text { Size } \\
\left(\mathrm{mm}^{2}\right)\end{array}$ & $\begin{array}{c}\text { Existing } \\
\text { Reinforcement } \\
\left(\mathrm{mm}^{2}\right)\end{array}$ & $\begin{array}{c}\text { Rebar } \\
\text { Percentage }\end{array}$ & $\begin{array}{c}\text { Reinforcement } \\
\text { Required } \\
\left(\mathrm{mm}^{2}\right)\end{array}$ & $\begin{array}{c}\text { Additional } \\
\text { Reinforcement } \\
\text { Required }\left(\mathrm{mm}^{2}\right)\end{array}$ & $\begin{array}{c}\text { Extra } \\
\text { Bars }\end{array}$ \\
\hline $\mathrm{C} 12$ & $230 \varnothing$ & $330 \varnothing$ & 1205.76 & 1.01 & 863.4 & 0 & \\
\hline $\mathrm{C} 13$ & $230 \varnothing$ & $330 \varnothing$ & 1205.76 & 1.02 & 871.9 & 0 & \\
\hline $\mathrm{C} 17$ & $230 \varnothing$ & $330 \varnothing$ & 1205.76 & 1.98 & 1692.6 & 486.8 & $4-16 \varnothing$ \\
\hline $\mathrm{C} 18$ & $230 \varnothing$ & $330 \varnothing$ & 1205.76 & 0.8 & 683.8 & 0 & \\
\hline $\mathrm{C} 19$ & $230 \varnothing$ & $330 \varnothing$ & 1205.76 & 0.8 & 683.8 & 0 & \\
\hline $\mathrm{C} 20$ & $230 \varnothing$ & $330 \varnothing$ & 1205.76 & 1.97 & 1684 & 478.3 & $4-16 \varnothing$ \\
\hline $\mathrm{C} 24$ & $230 \varnothing$ & $330 \varnothing$ & 1205.76 & 0.8 & 683.8 & 0 & \\
\hline $\mathrm{C} 25$ & $230 \varnothing$ & $330 \varnothing$ & 1205.76 & 1.23 & 1051.4 & 0 & \\
\hline $\mathrm{C} 26$ & $230 \varnothing$ & $330 \varnothing$ & 1205.76 & 3.49 & 2983.4 & 1777 & $4-20 \emptyset$ \\
\hline $\mathrm{C} 27$ & $230 \varnothing$ & $330 \varnothing$ & 1205.76 & 3.6 & 3077.5 & 1871 & $4-20 \varnothing$ \\
\hline $\mathrm{C} 28$ & $230 \varnothing$ & $330 \varnothing$ & 1205.76 & 1.21 & 1034.3 & 0 & \\
\hline $\mathrm{C} 29$ & $230 \varnothing$ & $330 \varnothing$ & 1205.76 & 0.8 & 683.8 & 0 & \\
\hline $\mathrm{C} 32$ & $230 \varnothing$ & $330 \varnothing$ & 1205.76 & 2.74 & 2342.3 & 1136 & $4-20 \varnothing$ \\
\hline $\mathrm{C} 33$ & $230 \varnothing$ & $330 \varnothing$ & 1205.76 & 2.61 & 2231.1 & 1025 & \\
\hline $\mathrm{C} 36$ & $230 \varnothing$ & $330 \varnothing$ & 1205.76 & 1.09 & 931.8 & 0 & \\
\hline $\mathrm{C} 37$ & $230 \varnothing$ & $330 \varnothing$ & 1205.76 & 0.8 & 683.8 & 0 & \\
\hline $\mathrm{C} 40$ & $500 \times 200$ & $600 \times 300$ & 1440 & 0.8 & 1440 & 0 & \\
\hline $\mathrm{C} 41$ & $500 \times 200$ & $600 \times 300$ & 1440 & 0.8 & 1440 & 0 & \\
\hline $\mathrm{C} 42$ & $500 \times 200$ & $600 \times 300$ & 1440 & 0.8 & 1440 & 0 & \\
\hline $\mathrm{C} 43$ & $500 \times 200$ & $600 \times 300$ & 1440 & 0.8 & 1440 & 0 & \\
\hline
\end{tabular}


Table A5 Proposed strengthening schemes for foundations

\begin{tabular}{|c|c|c|c|c|c|}
\hline \multirow[t]{2}{*}{ Column } & \multirow[t]{2}{*}{ Existing Size } & \multirow[t]{2}{*}{ Remarks } & \multirow{2}{*}{$\begin{array}{c}\text { Proposed } \\
\text { size }\end{array}$} & \multicolumn{2}{|c|}{ Depth } \\
\hline & & & & existing & Proposed \\
\hline $\mathrm{C} 1$ & $2500 \times 980$ & Valid Design & & & \\
\hline $\mathrm{C} 2$ & $2500 \times 980$ & Fails on GBP & $2500 \times 1065$ & 450 & 450 \\
\hline $\mathrm{C} 3$ & $2500 \times 980$ & Fails on GBP & $2500 \times 1255$ & 450 & 450 \\
\hline $\mathrm{C} 4$ & $2500 \times 980$ & Fails on GBP & $2500 \times 1270$ & 450 & 450 \\
\hline $\mathrm{C} 5$ & $2500 \times 980$ & Fails on GBP & $2500 \times 1170$ & 450 & 450 \\
\hline C6 & $2500 \times 980$ & Valid Design & & 450 & 450 \\
\hline $\mathrm{C} 7$ & $2500 \times 980$ & Valid Design & & & \\
\hline $\mathrm{C} 8$ & $1600 \times 1600$ & Fails on GBP & $1650 \times 1650$ & 450 & 450 \\
\hline C9 & $1600 \times 1600$ & Fails on GBP & $1660 \times 1660$ & 450 & 450 \\
\hline $\mathrm{C} 10$ & $2500 \times 980$ & Valid Design & & 450 & 450 \\
\hline $\mathrm{C} 11$ & $2500 \times 980$ & Fails on GBP & $2500 \times 1030$ & 450 & 450 \\
\hline $\mathrm{C} 12$ & $1600 \times 1600$ & Fails on GBP & $1880 x 1880$ & 450 & 450 \\
\hline C13 & $1600 \times 1600$ & Fails on GBP & $1880 \times 1880$ & 450 & 450 \\
\hline C14 & $2500 \times 980$ & Fails on GBP & $2500 \times 1225$ & 450 & 450 \\
\hline $\mathrm{C} 15$ & $2500 \times 980$ & Valid Design & & & \\
\hline C16 & $1600 \times 1600$ & Fails on GBP & $1675 \times 1675$ & 450 & 450 \\
\hline C17 & $1600 \times 1600$ & Fails on GBP & $2175 \times 2175$ & 450 & 460 \\
\hline $\mathrm{C} 18$ & $1600 \times 1600$ & Fails on GBP & $1870 \times 1870$ & 450 & 450 \\
\hline C19 & $1600 \times 1600$ & Fails on GBP & $1870 \times 1870$ & 450 & 450 \\
\hline $\mathrm{C} 20$ & $1600 \times 1600$ & Fails on GBP & $2170 \times 2170$ & 450 & 450 \\
\hline $\mathrm{C} 21$ & $1600 \times 1600$ & Fails on GBP & $1715 \times 1715$ & 450 & 450 \\
\hline $\mathrm{C} 22$ & $2500 \times 980$ & Fails on GBP & $2500 \times 1225$ & 450 & 450 \\
\hline $\mathrm{C} 23$ & $2500 \times 980$ & Valid Design & & & \\
\hline $\mathrm{C} 24$ & $1600 \times 1600$ & Fails on GBP & $1815 \times 1815$ & 450 & 450 \\
\hline $\mathrm{C} 25$ & $1600 \times 1600$ & Fails on GBP & $2225 \times 2225$ & 450 & 500 \\
\hline $\mathrm{C} 26$ & $1600 \times 1600$ & Fails on GBP & $2465 \times 2465$ & 450 & 600 \\
\hline $\mathrm{C} 27$ & $1600 \times 1600$ & Fails on GBP & $2475 \times 2475$ & 450 & 610 \\
\hline $\mathrm{C} 28$ & $1600 \times 1600$ & Fails on GBP & $2215 \times 2215$ & 450 & 500 \\
\hline $\mathrm{C} 29$ & $1600 \times 1600$ & Fails on GBP & $1845 \times 1845$ & 450 & 450 \\
\hline $\mathrm{C} 30$ & $2500 \times 980$ & Fails on GBP & $2500 \times 1340$ & 450 & 450 \\
\hline $\mathrm{C} 31$ & $2500 \times 980$ & Fails on GBP & $2500 \times 1390$ & 450 & 450 \\
\hline C32 & $1600 \times 1600$ & Fails on GBP & $2365 \times 2365$ & 450 & 570 \\
\hline C33 & $1600 \times 1600$ & Fails on GBP & $2325 \times 2325$ & 450 & 550 \\
\hline $\mathrm{C} 34$ & $2500 \times 980$ & Fails on GBP & $2500 \times 1510$ & 450 & 450 \\
\hline C35 & $2500 \times 980$ & Fails on GBP & $2500 \times 1155$ & 450 & 450 \\
\hline C36 & $1600 \times 1600$ & Fails on GBP & $2040 \times 2040$ & 450 & 450 \\
\hline $\mathrm{C} 37$ & $1600 \times 1600$ & Fails on GBP & $1925 \times 1925$ & 450 & 450 \\
\hline C38 & $2500 \times 980$ & Fails on GBP & $2500 \times 1100$ & 450 & 450 \\
\hline C39 & $2500 \times 980$ & Fails on GBP & $2500 \times 1145$ & 450 & 450 \\
\hline $\mathrm{C} 40$ & $2500 \times 980$ & Fails on GBP & $2500 \times 1600$ & 450 & 450 \\
\hline C41 & $2500 \times 980$ & Fails on GBP & $2500 \times 2130$ & 450 & 530 \\
\hline $\mathrm{C} 42$ & $2500 \times 980$ & Fails on GBP & $2500 \times 2170$ & 450 & 550 \\
\hline $\mathrm{C} 43$ & $2500 \times 980$ & Fails on GBP & $2500 \times 1680$ & 450 & 450 \\
\hline C44 & $2500 \times 980$ & Fails on GBP & $2500 \times 1135$ & 450 & 450 \\
\hline
\end{tabular}

